\title{
LA-UR-18-26650
}

Approved for public release; distribution is unlimited.

Title: $\quad$ MIS High-Purity Plutonium Oxide Metal Oxidation Product BLO-39-11-14-004 (SSR132 and 132A): Final Report

Author(s): $\quad$ Veirs, Douglas Kirk

Stroud, Mary Ann

Martinez, Max

Carrillo, Alex

Berg, John M.

Narlesky, Joshua Edward

Worl, Laura Ann

Intended for: Report

Issued: 
Disclaimer:

Los Alamos National Laboratory, an affirmative action/equal opportunity employer, is operated by the Los Alamos National Security, LLC for the National Nuclear Security Administration of the U.S. Department of Energy under contract DE-AC52-06NA25396. By approving this article, the publisher recognizes that the U.S. Government retains nonexclusive, royalty-free license to publish or reproduce the published form of this contribution, or to allow others to do so, for U.S. Government purposes. Los Alamos National Laboratory requests that the publisher identify this article as work performed under the auspices of the U.S. Department of Energy. Los Alamos National Laboratory strongly supports academic freedom and a researcher's right to publish; as an institution, however, the Laboratory does not endorse the viewpoint of a publication or guarantee its technical correctness. 


\section{MIS High-Purity Plutonium Oxide Metal Oxidation Product BLO-39-11-14- 004 (SSR132 and 132A): Final Report}

Authors:

D. Kirk Veirs

Mary A. Stroud

Max A. Martinez (retired)

Alex Carrillo (retired)

John M. Berg

Joshua E. Narlesky

Laura Worl 


\title{
MIS High-Purity Plutonium Oxide Metal Oxidation Product BLO-39-11-14-004
} (SSR132 and 132A): Final Report

\begin{abstract}
A high-purity, reactor-grade plutonium dioxide material from the Material Identification and Surveillance (MIS) Program inventory has been studied with regard to gas generation and corrosion in a storage environment. BLO-39-11-14-004 is a high specific power oxide that represents Hanford process plutonium oxides from oxalate process product, oxalate precipitation of impure plutonium and pure mixed uranium/plutonium nitrate solutions, PFP NDA and impure and scrap plutonium oxides $80-85 \%$ from PFP and the 300 area. It also represents plutonium oxides from oxalate precipitation at LANL and Savannah River. After calcination to $950{ }^{\circ} \mathrm{C}$, the material contained $80 \%$ plutonium and $7 \%$ americium with no major impurities. This study followed over time the gas pressure of a sample with nominally $0.5 \mathrm{wt} \%$ water in a sealed container with an internal volume scaled to $1 / 500^{\text {th }}$ of the volume of a 3013 container. A leak occurred in the original reactor (SSR132) which was terminated after 3 years. The sample was reloaded (SSR132A) and an additional set of data was collected. Results from both loadings are discussed. Gas compositions were measured periodically over three (SSR132) and four and a half (SSR132A) year periods. The maximum observed gas pressures were $93 \mathrm{kPa}$ and $94 \mathrm{kPa}$, respectively. The increase over the initial pressure was primarily due to generation of nitrogen gas. For SSR132, the maximum observed gas pressure for hydrogen was $1.2 \mathrm{kPa}$ and oxygen was $9.3 \mathrm{kPa}$ (includes oxygen from leak). For SSR132A, the maximum observed gas pressure for hydrogen was $5.5 \mathrm{kPa}$ and oxygen was $0.9 \mathrm{kPa}$. At the completion of the study, the internal components of the sealed container showed limited signs of corrosion.
\end{abstract}




\section{Contents}

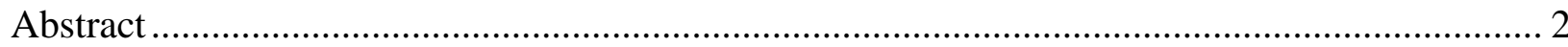

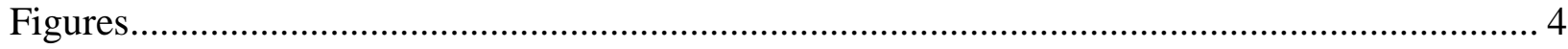

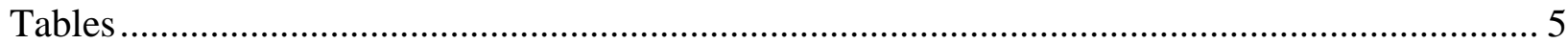

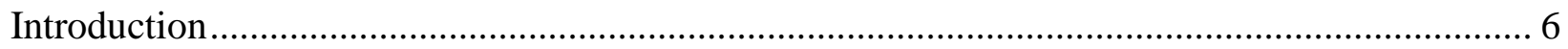

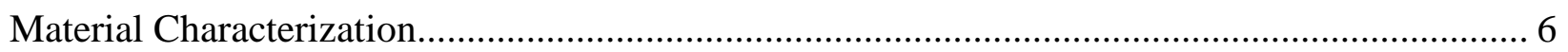

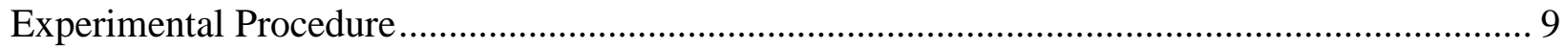

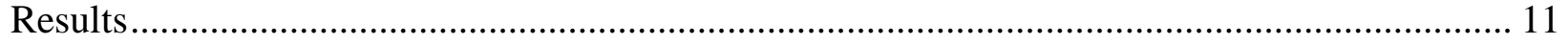

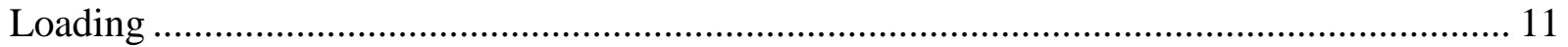

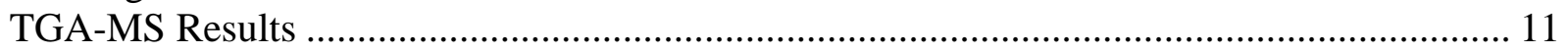

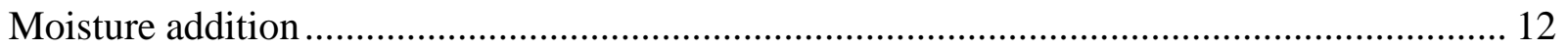

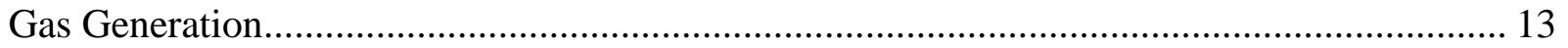

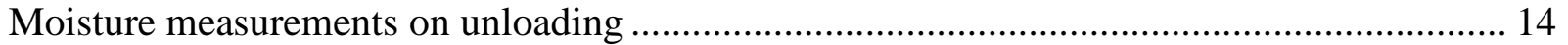

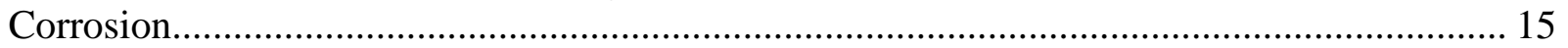

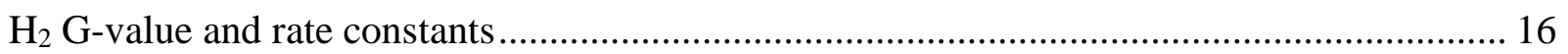

Estimation of the amount of moisture on the material during the gas generation study .......... 19

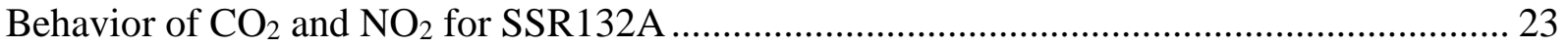

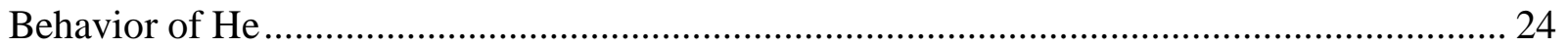

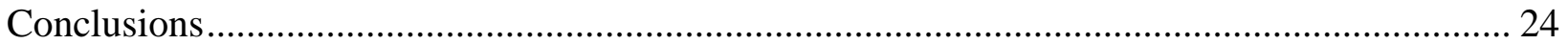

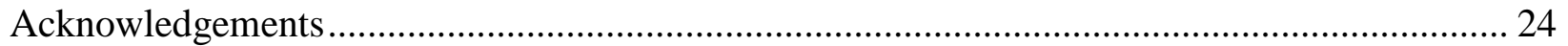

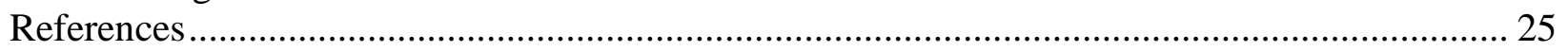

Appendix 1, Gas Generation Partial Pressure Data and Uncertainties in kPa .......................... 26

Appendix , Gas Generation: Total Pressure for SSR132 ..................................................... 29

Appendix 3, Gas Generation: Total Pressure for SSR132A ................................................. 31

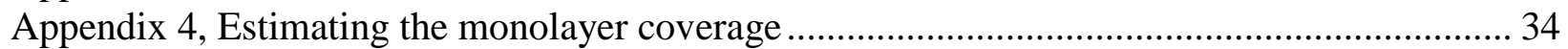

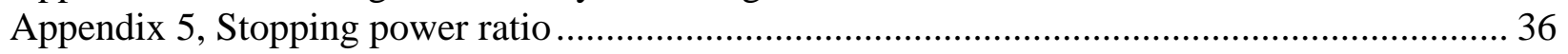

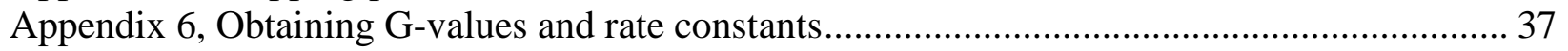

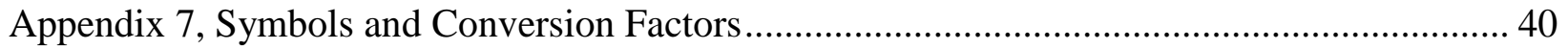




\section{Figures}

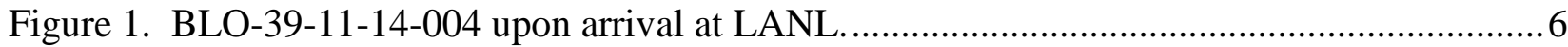

Figure 2. The specific power of BLO-39-11-14-004 as a function of time from the isotopic measurement date in August 29, 2002. The vertical green lines bound the time the sample was in SSR132 and vertical purple bound the time for SSR132A.

Figure 3. Rate of He evolved from alpha decay (blue line/left axis) as a function of time and the moles of He per kg material per 0.1 year (red line/right axis). The vertical green lines bound the time the sample was in SSR132 and vertical purple bound the time for SSR132A

Figure 4. Dissassembled SSR: Conflat container body (A) with Conflat flange lid (B), copper gasket (C), inner bucket (D), pressure transducer (E), and a sampling volume between two sampling valves with connection to the gas manifold (F), Inner bucket slides into container body and holds the material.

Figure 5. TGA-MS data for the parent material loaded into SSR132. Mass 17.00 and 18.00 are $\mathrm{H}_{2} \mathrm{O}$ and Mass 44 is $\mathrm{CO}_{2}$

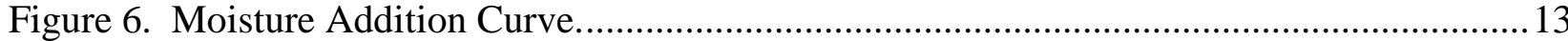

Figure 7. Total pressure and partial pressure of gases measured using a gas chromatograph as a function of time. He and Total pressure are plotted on the left primary scale.

Figure 8. Photographs after unloading: a) inner bucket of SSR132 b) inner bucket of SSR132A c) close up of SSR132A section A d) close up of SSR132A section C and e) close up of SSR132A section B.

Figure 9. The hydrogen partial pressure and the fit to Equation 6, or first order formation and first order consumption reaction with an $\mathrm{r}^{2}$ coefficient of 0.85 . 18

Figure 10. Graph of the estimated active water, A(t), in SSR132A as a function of time, where $A_{0}$ is expressed in terms of wt\% of water.

Figure 11. Comparison of calculated $\mathrm{G}\left(\mathrm{H}_{2}\right)$ plotted against the number of calculated water monolayers determined in this study with those from previous research. 


\section{Tables}

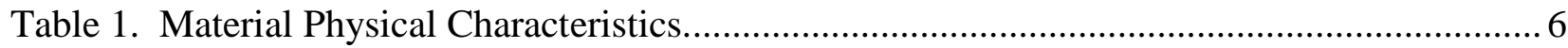

Table 2. Elemental weight \% of impurities. ....................................................................... 7

Table 3. Isotopic data listed as mass fraction (g/g plutonium) obtained from calorimetry/gamma. Specific power is reported in $\mathrm{mW}$ per gram of material, not per gram of plutonium. ...... 7

Table 4. Mass of sample and results of calculation of free gas volume using approach in Obtaining G-values and rate constants from MIS data Appendix A. ${ }^{5}$.......................... 11

Table 5. Moisture data summary at loading.................................................................... 12

Table 6. Unloading moisture data summary for SSR132A. ................................................ 15

Table 7. The fit parameters based on the reaction model, standard errors and initial rate from the hydrogen generation data for SSR132A at $55^{\circ} \mathrm{C}$ from Eq 6.................................... 18

Table 8. The amount of water adsorbed on the material, in the gas phase, and decomposed to form $\mathrm{H}_{2}$ expressed as moles, grams, and monolayers. The mass of water in a monolayer is 0.0013 g. Calculations use SSA $=2.4 \mathrm{~m}^{2} \mathrm{~g}^{-1}, \mathrm{~m}_{\text {mat }}=2.51 \mathrm{~g}$ and $\mathrm{V}_{\text {gas }}=5.093 \mathrm{~cm}^{3}$. The amount of strongly bound chemisorbed water on the material was assumed to be 1.5 monolayers $\mathrm{wt} \%$ at all times.

Table 9. $\mathrm{G}\left(\mathrm{H}_{2}\right)$ calculated from reaction parameters and estimated moisture content using equation A6-4 in Appendix 6 assuming radiolytic decomposition of water to form $\mathrm{H}_{2} .22$

Table 10. Rate constants calculated from the reaction parameters and the estimated moisture content assuming surface catalyzed decomposition of water to form $\mathrm{H}_{2} \ldots \ldots \ldots \ldots \ldots \ldots \ldots . . . . .22$

Table 11. Amount of nitrogen species detected on the surface prior to loading compared to the amount detected in the gas phase 


\section{Introduction}

The Los Alamos National Laboratory (LANL) Shelf-life Surveillance project was established under the Material Identification and Surveillance (MIS) Program to identify early indications of potential failure mechanisms in 3013 containers. ${ }^{1}$ Samples were taken from plutonium processes across the DOE complex. These "representative" materials were sent to LANL to be included in the MIS inventory. ${ }^{2}$ The small-scale surveillance project is designed to provide gas generation and corrosion information of the MIS represented materials under worst-case moisture loadings. This information, in combination with material characterization, allows predictions of the behavior of 3013 packaged materials stored at DOE sites. Pressure, gas compositions, and corrosion were monitored in small-scale reactors (SSRs) charged with nominally 10 gram samples of plutonium bearing materials with nominally $0.5 \mathrm{wt} \%$ water, the upper limit allowed by the DOE's 3013 Standard. ${ }^{1}$ In this case, however, a 2.5 gram sample was used. The 3013 Standard only allows a total of 19 Watts within a container and the specific power of BLO material, approximately $14 \mathrm{~W} / \mathrm{kg}$, results in approximately one-quarter of a normally allowed 5.0 $\mathrm{kg}$ loading. The sample used for this study is approximately one-quarter of the normal 10 gram sample.

This report discusses sample BLO-39-11-14-004, a highpurity, reactor-grade plutonium $(\mathrm{Pu})$ dioxide material from the MIS Program inventory that originated in the Hanford continuous oxalate precipitation and calcination process from purified nitrate solution produced in the PFP RMA line. BLO-39-11-14-004 plutonium oxide is representative of oxides generated from the following processes:

- Oxalate Process Product at Hanford

- Oxalate Precipitation of Impure Plutonium Nitrate Solutions at Hanford

- Oxalate precipitation of Pure Mixed Uranium/Plutonium Nitrate Solutions at Hanford

- Oxide from Oxalate Precipitation at Savannah River

- Oxide Precipitation from Nitrate Solutions at LANL ${ }^{3}$

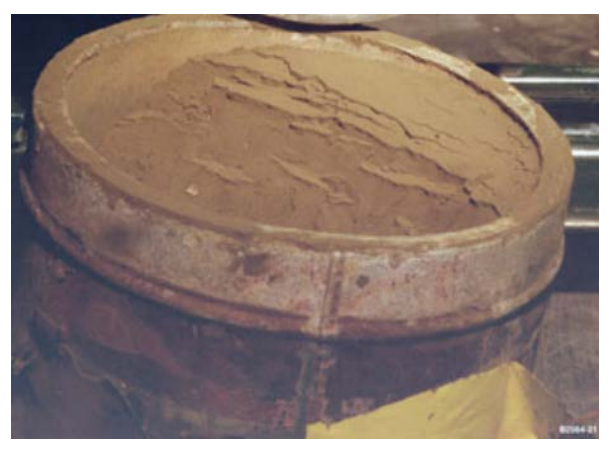

Figure 1. BLO-39-11-14-004 upon arrival at LANL.

\section{Material Characterization}

The reactor-grade plutonium oxide, shown in Figure 1, was calcined at $950{ }^{\circ} \mathrm{C}$ for 2 hours on June 19, 1997. Several measurements of material characteristics that were obtained on the calcined sample are summarized in Table 1 . The material loaded in the reactor was all calcined to $950{ }^{\circ} \mathrm{C}$. The material was re-calcined to $950^{\circ} \mathrm{C}$ in 2017 and the specific surface area (SSA) was measured.

Table 1. Material Physical Characteristics.

\begin{tabular}{|c|c|}
\hline Specific Surface Area (SSA) 5-point $\left(\mathrm{m}^{2} \mathrm{~g}^{-1}\right)$ & 2.4 \\
\hline Bulk Density $\left(\mathrm{g} \mathrm{cm}^{-3}\right)$ & 2.7 \\
\hline Tap Density $\left(\mathrm{g} \mathrm{cm}^{-3}\right)$ & 3.4 \\
\hline Pycnometer Density $\left(\mathrm{g} \mathrm{cm}^{-3}\right)$ & 10.77 \\
\hline
\end{tabular}


Table 2 summarizes the wt\% of key elements as well as any impurity present as $0.01 \mathrm{wt} \%$ or greater. Oxygen is not measured and it is assumed to make up the difference between the sum of the listed elements plus plutonium and americium and 100\%. No measurements of soluble species were conducted for this material.

Table 2. Elemental weight \% of impurities.

\begin{tabular}{|c|c|}
\hline Element & wt \% \\
\hline Calcium & 0.008 \\
\hline Iron & 0.049 \\
\hline Magnesium & 0.084 \\
\hline Phosphorus & 0.058 \\
\hline Potasium & 0.049 \\
\hline Silicon & 0.021 \\
\hline Sodium & $<0.003$ \\
\hline Thorium & 0.05 \\
\hline
\end{tabular}

Isotopics and wattage data from calorimetry/gamma isotopics, obtained on the calcined parent material on August 29, 2002, are listed in Table 3.

Table 3. Isotopic data listed as mass fraction (g/g plutonium) obtained from calorimetry/gamma. Specific power is reported in $\mathrm{mW}$ per gram of material, not per gram of plutonium.

\begin{tabular}{|l|l|}
\hline Isotope & $\begin{array}{l}\text { Mass Fraction } \\
(\mathrm{g} / \mathrm{gPu})\end{array}$ \\
\hline $\mathrm{Pu}-238$ & 0.0079654 \\
\hline $\mathrm{Pu}-239$ & 0.7709402 \\
\hline $\mathrm{Pu}-240$ & 0.1954343 \\
\hline $\mathrm{Pu}-241$ & 0.02211 \\
\hline $\mathrm{Pu}-242$ & 0.0035500 \\
\hline Am-241 & 0.0861854 \\
\hline
\end{tabular}

\begin{tabular}{|l|l|}
\hline $\begin{array}{l}\text { Total Plutonium } \\
\text { (g Pu/g of material) }\end{array}$ & 0.80 \\
\hline $\begin{array}{l}\text { Total Actinide content } \\
\text { (g Pu + Am/g of material) }\end{array}$ & 0.864 \\
\hline Specific Power (mW/g of material) & 13.77 \\
\hline
\end{tabular}

The specific power of reactor-grade BLO-39-11-14-004 as a function of time from the isotopic measurement date is shown in Figure 2. The high specific power of the material is primarily due to in-growth of Am which reached approximately $7 \%$ in the material 


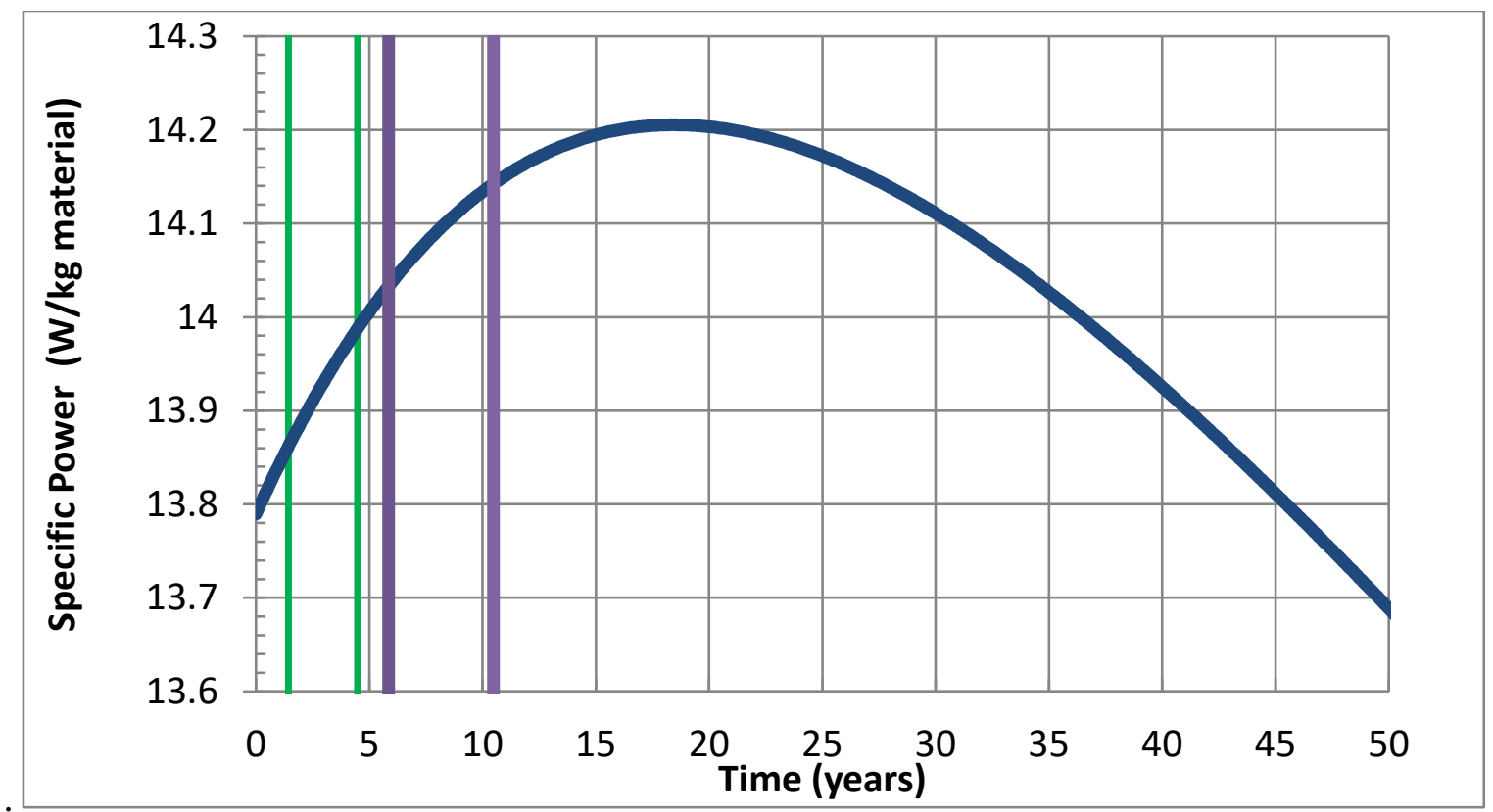

Figure 2. The specific power of BLO-39-11-14-004 as a function of time from the isotopic measurement date in August 29, 2002. The vertical green lines bound the time the sample was in SSR132 and vertical purple bound the time for SSR132A.

Figure 3 provides information on He evolution as a function of time in BLO-39-11-14-004.

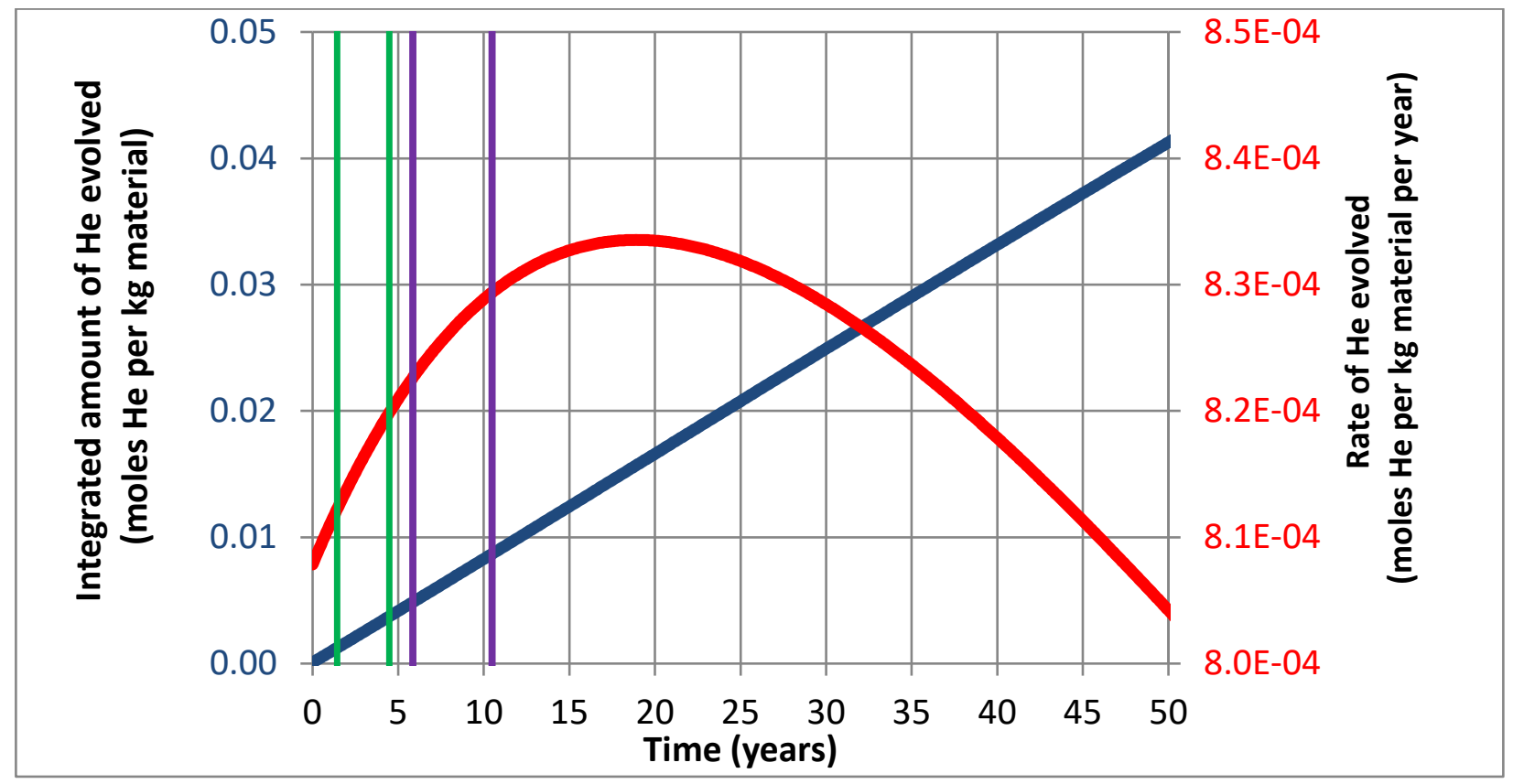

Figure 3. Rate of He evolved from alpha decay (blue line/left axis) as a function of time and the moles of He per kg material per 0.1 year (red line/right axis). The vertical green lines bound the time the sample was in SSR132 and vertical purple bound the time for SSR132A. 


\section{Experimental Procedure}

The design of the small-scale reactor (SSR) system has been described previously. ${ }^{4}$ The container's nominally five $\mathrm{cm}^{3}$ internal volume is scaled to $\sim 1 / 500^{\text {th }}$ of the inner 3013 storage container. The material of construction of the inner small-scale containers is 304L stainless steel. The SSR consists of a container body ${ }^{5}$ welded into a Conflat flange and a lid consisting of a Conflat flange with tubing attachments for connections to a pressure transducer and a gas manifold. An inner bucket is used to hold material and is inserted into the container body during the loading activities. The inner bucket allows the fine plutonium oxide powder to be handled with minimal or no spillage. A low-internal-volume pressure transducer and associated lowvolume tubing is attached to the lid. Small-scale reactors have interchangeable parts with varying volumes. For this study, a Type $\mathrm{H}$ container with a total internal volume of $5.326 \mathrm{~cm}^{3}$ was used. ${ }^{5}$ The gas sampling volume located between two sampling valves, $0.05 \mathrm{~cm}^{3}(\sim 1 \%$ of the SSR volume), allows gas composition to be determined with minimal effect on the internal gas pressure. A disassembled SSR is shown in Figure 4.

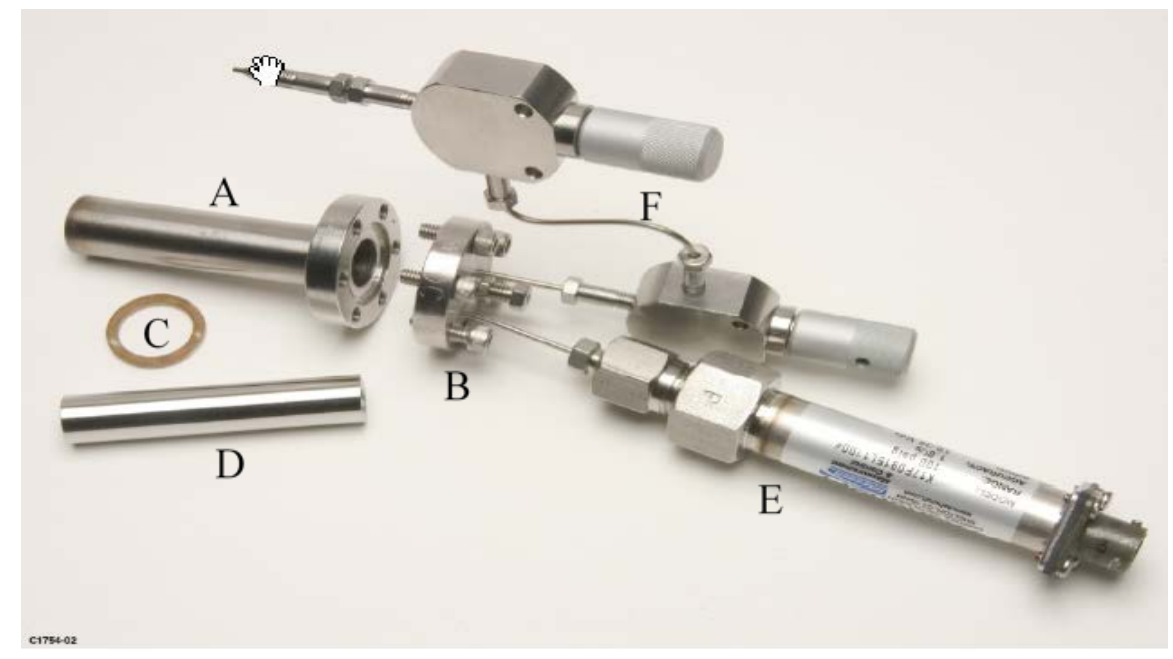

Figure 4. Dissassembled SSR: Conflat container body (A) with Conflat flange lid (B), copper gasket (C), inner bucket (D), pressure transducer (E), and a sampling volume between two sampling valves with connection to the gas manifold (F), Inner bucket slides into container body and holds the material.

Gas generation is to be characterized for each MIS represented material at the bounding moisture content of $0.5 \mathrm{wt} \%$. The procedure to achieve $0.5 \mathrm{wt} \%$ moisture included (1) estimating the moisture content of the material as it was received for small-scale loading and (2) adding sufficient water to bring the total to $0.5 \mathrm{wt} \%$. For SSR132, the moisture content of the material was estimated by weight loss upon heating to $200^{\circ} \mathrm{C}$ (LOI-200 ${ }^{\circ} \mathrm{C}$ ) of a one gram sample that was cut from the parent lot at the same time as the small-scale sample. The LOI- $200{ }^{\circ} \mathrm{C}$ sample was placed in a glass vial which remained in the glove box line with the small-scale sample until the LOI- $200{ }^{\circ} \mathrm{C}$ measurement was performed, typically one day or less after the sample split and just prior to SSR loading. LOI- $200{ }^{\circ} \mathrm{C}$ involved heating nominally one gram of the material for 2 hours at $200{ }^{\circ} \mathrm{C}$, cooling the material for 10 minutes and determining the mass difference of the material before and after heating. The mass loss observed was attributed to adsorbed water. It is assumed that the $\mathrm{LOI}-200{ }^{\circ} \mathrm{C}$ material contained additional water as hydroxyls or chemically 
adsorbed water which was not removed by heating to $200{ }^{\circ} \mathrm{C}$ and was not quantified. ${ }^{6}$ The amount of water to be added to achieve $0.5 \mathrm{wt} \%$ total moisture was calculated as the difference between $0.5 \mathrm{wt} \%$ and the mass loss water by LOI- $200{ }^{\circ} \mathrm{C}$. (No estimate of chemically adsorbed water was included in the sum to $0.5 \mathrm{wt} \%$ ).For SSR132A, the entire $2.5 \mathrm{~g}$ sample was heated for 2 hours at $200{ }^{\circ} \mathrm{C}$ to remove adsorbed water. The target amount of water added was $0.5 \mathrm{wt} \%$. In addition, samples from the parents were split and placed in glass vials inside hermetically sealed containers. The water content of both samples were determined by Thermal Gravametric Analysis-Mass Spectroscopy (TGA-MS). TGA-MS is inherently more accurate than LOI-200 ${ }^{\circ} \mathrm{C}$, although there can be errors associated with this method due to handling and excessive times before the sample is run. The TGA-MS results were not available at the time of loading.

The procedure to add moisture is described briefly. A 2.5-gram sample of the BLO-39-11-14-004 material was placed on a balance in a humidified chamber. Weight gain was recorded as a function of time. The sample was then placed into a small-scale reactor. The glove boxes used for loading and surveillance were flushed with He, resulting in a glove box atmosphere of mainly He with a small amount of air. Some moisture loss was expected during transfer from the humidified chamber into the SSR in the very dry glove box atmosphere (relative humidity $<0.1$ \%). Transfer time from the balance where the final mass measurement is made to when the SSR was sealed was kept to approximately 45 seconds. Weight loss during transfer for other highpurity oxide samples was measured to and averaged $0.07 \mathrm{wt} \%$ per minute. ${ }^{7}$ Therefore $0.05 \%$ was assumed to have been lost during the 45 seconds of loading when estimating total moisture content at loading.

The sealed SSR was placed in a heated sample array maintained at $55^{\circ} \mathrm{C}$. Fifty microliter gas samples were extracted through a gas mainfold. . Fifty microliters corresponds to $0.98 \%$ of the free gas volume. The average pressure drop on taking the gas sample was also $0.98 \%$. The gas sample was analyzed using an Agilent 5890 GC (gas chromatograph) calibrated for $\mathrm{He}_{2} \mathrm{H}_{2}, \mathrm{~N}_{2}$, $\mathrm{O}_{2}, \mathrm{CO}_{2}, \mathrm{CO}, \mathrm{CH}_{4}$ and $\mathrm{N}_{2} \mathrm{O}$. Water vapor was not measured in these samples. The pressure and array temperature was recorded every fifteen minutes. The pressure data was reduced to weekly average values reported here. Gas composition was sampled at least annually.

At the termination of the experiment, a final GC gas sample was taken, and the SSR was removed from the array and allowed to cool to glove box temperature. The SSR lid was removed and a new lid containing a relative humidity sensor was placed on the container. The relative humidity and temperature in the container were measured using a Vaisala HMT330 sensor and readout after an equlibration time whose length was not measured but thought to be sufficient for $1 \%$ accuracy. The material was then removed from the container and the moisture content in the material was determined by performing LOI-200 ${ }^{\circ} \mathrm{C}$. 


\section{Results}

\section{Loading}

A 2.5 gram split from the parent material calcined to $950^{\circ} \mathrm{C}$ was selected for loading into the $\mathrm{SSR}$. The mass of the sample prior to moisture loading, $\mathrm{m}_{\text {mat }}$, the volume the material occupies calculated from $\mathrm{m}_{\text {mat }}$ and the pycnometer density, $\mathrm{V}_{\text {mat }}$, and the calculated free gas volume within the SSR, $\mathrm{V}_{\text {gas}}$, during the gas generation study are given in Table 4. A leak occurred in the original reactor (SSR132) which was terminated after 3 years. The sample was reloaded (SSR132A) and an additional set of data was collected.

Table 4. Mass of sample and results of calculation of free gas volume using approach in Obtaining G-values and rate constants from MIS data Appendix A. ${ }^{5}$

\begin{tabular}{|c|c|c|c|c|}
\hline SSR & $\begin{array}{c}\text { Mass of sample } \\
\mathrm{m}_{\text {mat }}\end{array}$ & $\begin{array}{c}\text { Volume of } \\
\text { Material } \mathrm{V}_{\text {mat }}\end{array}$ & $\begin{array}{c}\text { Volume of SSR } \\
\mathrm{V}_{\text {SSR }}\end{array}$ & $\begin{array}{c}\text { Free Gas Volume in } \\
\text { SSR V }\end{array}$ \\
\hline 132 & $2.5400 \mathrm{~g}$ & $0.236 \mathrm{~cm}^{3}$ & $5.326 \mathrm{~cm}^{3}$ & $5.090 \mathrm{~cm}^{3}$ \\
\hline $132 \mathrm{~A}$ & $2.5061 \mathrm{~g}$ & $0.233 \mathrm{~cm}^{3}$ & $5.326 \mathrm{~cm}^{3}$ & $5.093 \mathrm{~cm}^{3}$ \\
\hline
\end{tabular}

\section{TGA-MS Results}

TGA-MS data for the sample from the material used in SSR132 are shown in Figure 5.

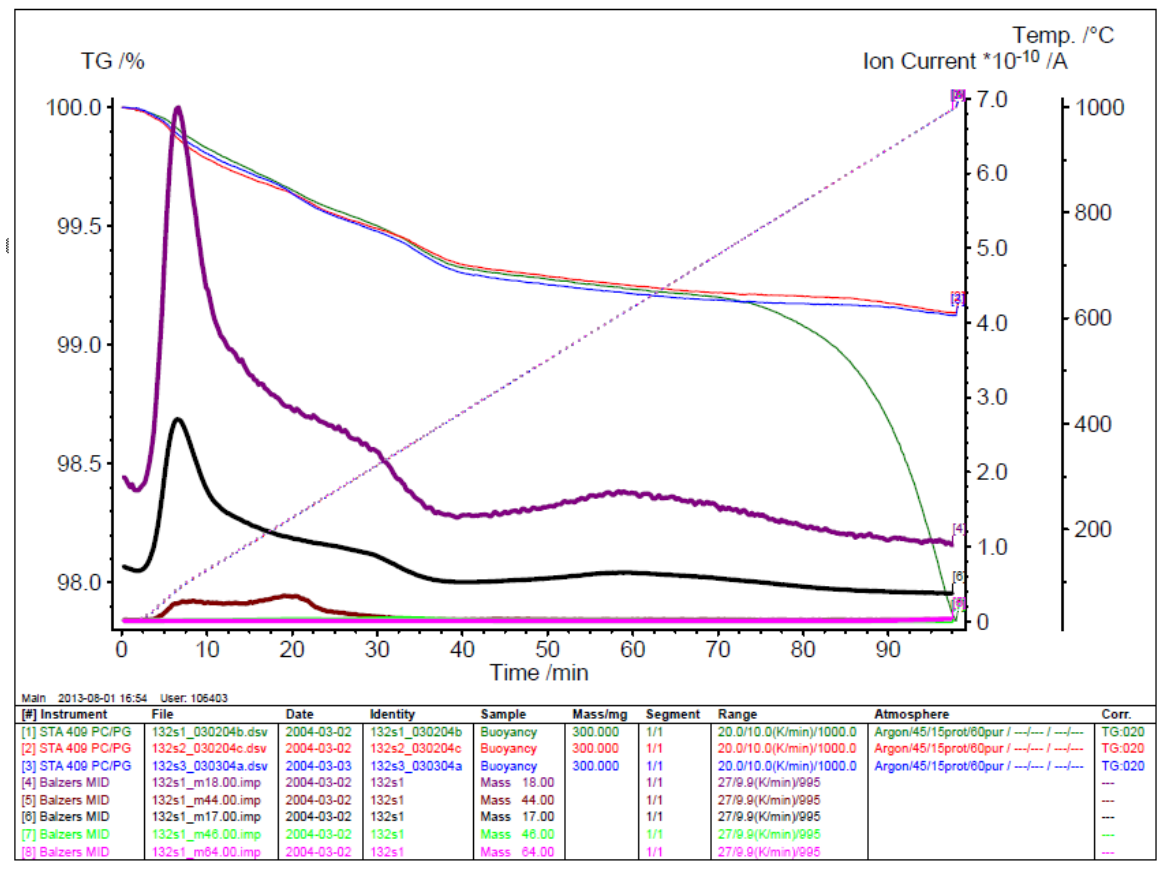

Figure 5. TGA-MS data for the parent material loaded into SSR132. Mass 17.00 and 18.00 are $\mathrm{H}_{2} \mathrm{O}$ and Mass 44 is $\mathrm{CO}_{2}$.

The sample was large enough to split into three subsamples. TGA traces for all three subsamples and MS traces for channels that were above background for one of the three samples are 
illustrated. Total moisture content was determined to be $0.48 \mathrm{wt} \%$. Other than water, carbon dioxide was the primary volatile below $400{ }^{\circ} \mathrm{C}$. During the TGA-MS analysis, $0.02 \mathrm{wt} \%$ carbon dioxide ( .0005 g in original sample) was measured. Nitrogen oxides were below quantifiable levels.

A graph of the TGA-MS data for the sample of the parent material in SSR132A is not available. TGA-MS total moisture content was determined to be $0.12 \mathrm{wt} \%$. During the TGA-MS analysis, $0.065 \mathrm{wt} \%$ carbon dioxide ( $.0016 \mathrm{~g}$ in original sample) was measured. Nitrogen oxides were below quantifiable levels.

The presence of surface adsorbed $\mathrm{CO}_{2}$ on aged material limits the accuracy of the LOI-200 ${ }^{\circ} \mathrm{C}$ techniques to estimate water content. For SSR132, the LOI-200 ${ }^{\circ} \mathrm{C}$ weight loss includes $\mathrm{CO}_{2}$ loss from this material that had been exposed to air for six to eleven years prior to the measurement.

\section{Moisture addition}

The measurements and assumptions used to estimate the true total moisture content at the time of loading are summarized in Table 5. The best estimate for the moisture content at loading is 0.60 wt\% for SSR132 and 0.59 wt\% for SSR132A, as given in Table 5 line 11, Estimated Total Moisture in loaded sample (using TGA-MS).

Table 5. Moisture data summary at loading.

\begin{tabular}{|c|c|c|c|c|}
\hline & Parameter & SSR132 & SSR132A & Units \\
\hline 1 & Original Calcination Date & 6/19/1997 & 6/19/1997 & \\
\hline 2 & Loading Date & $1 / 8 / 2004$ & $6 / 10 / 2008$ & \\
\hline 3 & Unloading Date & $1 / 25 / 2007$ & $1 / 28 / 2013$ & \\
\hline 4 & Initial sample weight $\left(\mathrm{m}_{\text {mat }}\right)$ & 2.540 & 2.5061 & g \\
\hline 5 & Initial Moisture (Total) by TGA-MS & 0.48 & 0.12 & $\mathrm{wt} \%$ \\
\hline 6 & Initial Moisture (Weakly bound) by LOI-200 ${ }^{\circ} \mathrm{C}$ & 0.29 & 0 & $\mathrm{wt} \%$ \\
\hline 7 & Total Moisture added & 0.17 & 0.52 & $\mathrm{wt} \%$ \\
\hline 8 & Relative Humidity in glove box during loading & $0.1 / 24.8$ & $0.1 /$ & $\% /{ }^{\circ} \mathrm{C}$ \\
\hline 9 & Estimated moisture loss during loading & 0.05 & 0.05 & $\mathrm{wt} \%$ \\
\hline 10 & $\begin{array}{l}\text { Estimated Weakly Bound Moisture in loaded } \\
\text { sample (using LOI) = Line } 6 \text { +Line } 7 \text {-Line } 9\end{array}$ & 0.41 & 0.47 & $\mathrm{wt} \%$ \\
\hline 11 & $\begin{array}{l}\text { Estimated Total Moisture in loaded sample (using } \\
\text { TGA-MS) = Line } 5+\text { Line } 7 \text {-Line } 9\end{array}$ & 0.60 & 0.59 & $\mathrm{wt} \%$ \\
\hline
\end{tabular}

The moisture uptake as a function of exposure time to a high humidity atmosphere is plotted in Figure 6 . The increase in mass is attributed to water adsorption by the material. Some loss of water occurs during the time when the material is transferred from the humidified chamber to the balance and the final mass measurement is made. The total moisture added to SSR132 in Table 5, $0.17 \mathrm{wt} \%$, is significantly less than the mass gain during moisture uptake, $0.26 \mathrm{wt} \%$, which may be due to a slow transfer. 


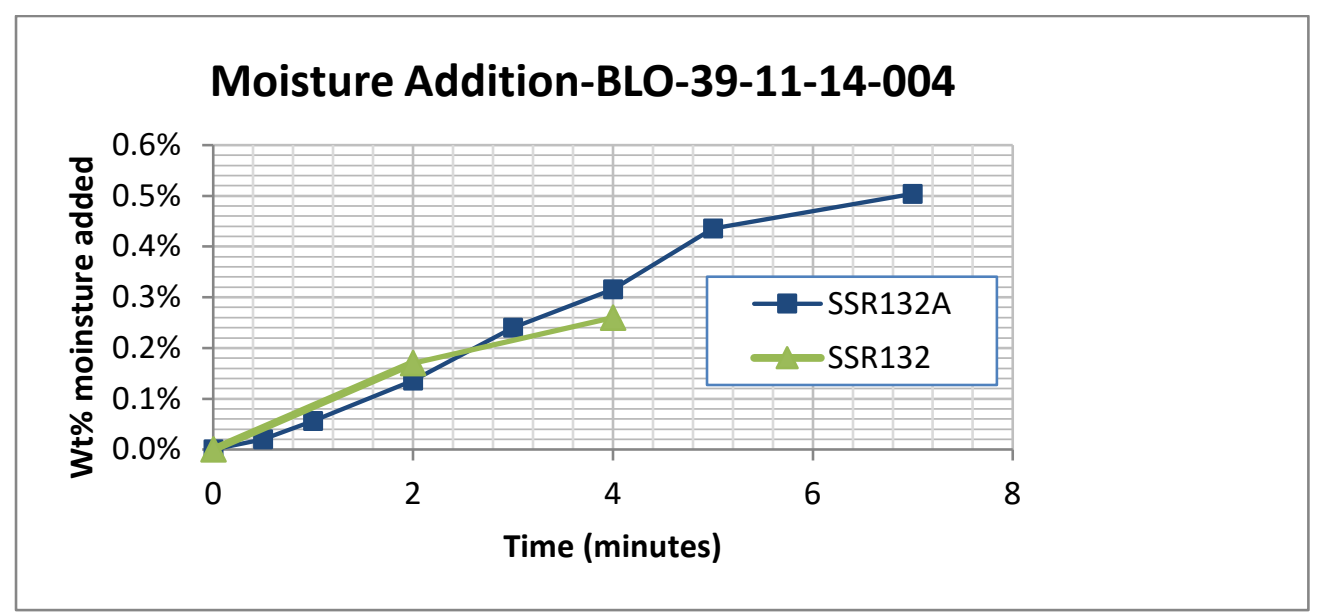

Figure 6. Moisture Addition Curve.

\section{Gas Generation}

The total pressure in SSR132A as a function of time, as well as the partial pressure of several gasses, is shown in Figure 7. Pressures reflect changes in the gasses in the reactor as well the $0.98 \%$ pressure drop due to gas sampling. In addition, the vapor pressure of water, estimated to be $4 \mathrm{kPa}$, is included in the total pressure, i.e. the sum of the partial pressures plotted and $4 \mathrm{kPa}$ for water equals the total pressure. Note that the total pressure increase is less than the partial pressure increases from generated gases mainly due to loss of He partial pressure from sampling. Data for SSR132 was not plotted due to the leak in the reactor. Detailed information on gas composition and uncertainties is in Appendix 1 and on pressure in Appendix 2 and 3.

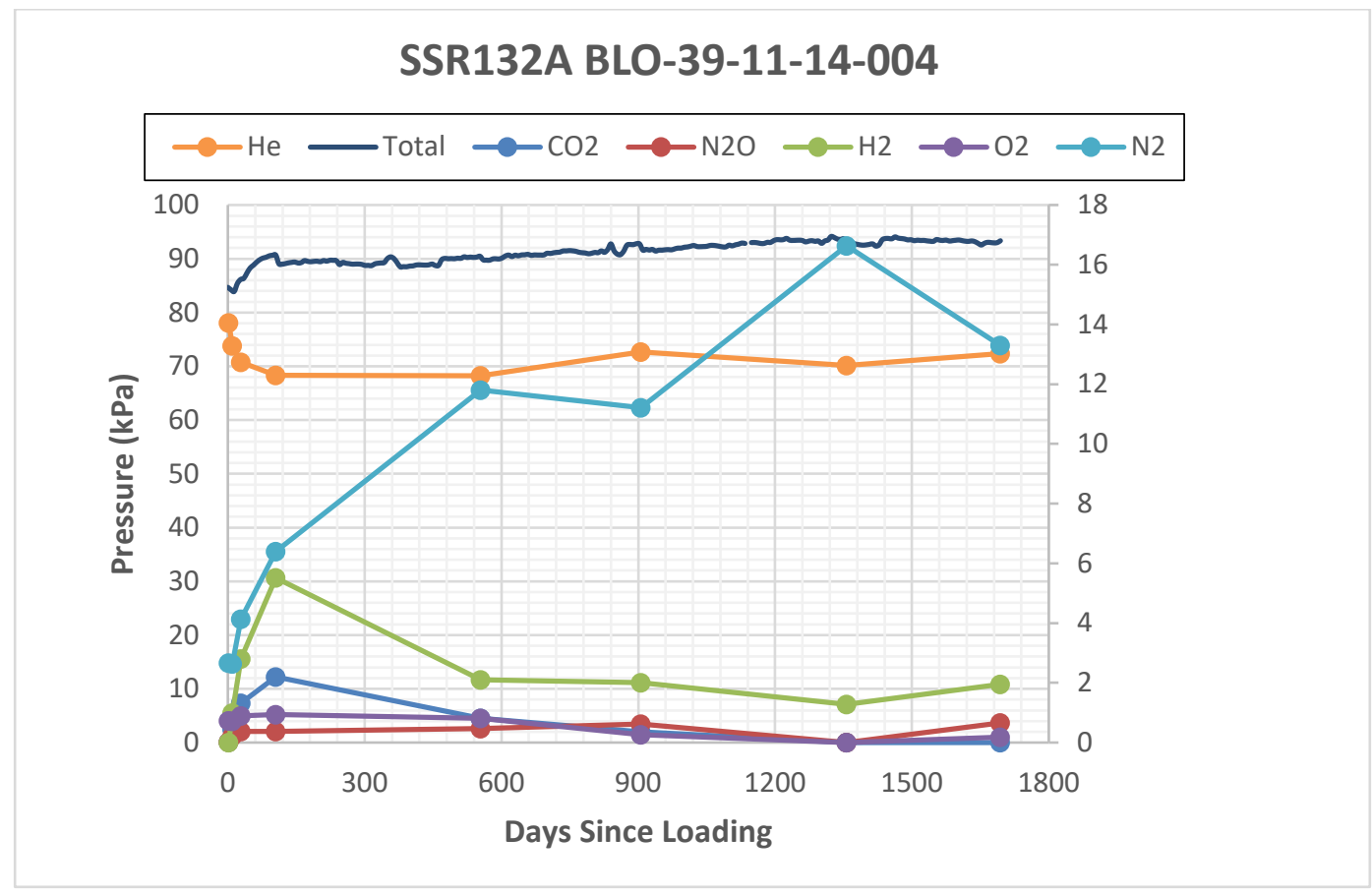

Figure 7. Total pressure and partial pressure of gases measured using a gas chromatograph as a function of time. He and Total pressure are plotted on the left primary scale. 
For SSR132A, the initial pressure of $85 \mathrm{kPa}$ increased over the first three months to $90 \mathrm{kPa}$, then gradually increased to a maximum pressure of $94 \mathrm{kPa}$ over the next 3.5 years. Hydrogen and oxygen were minor components in the headspace gas. Hydrogen was initially $0 \mathrm{kPa}$ and increased to $5.5 \mathrm{kPa}$ after 100 days then decreased over the next year to a final value of $1-2 \mathrm{kPa}$. Oxygen began at $0.6 \mathrm{kPa}$, increased slightly to $0.8 \mathrm{kPa}$ in the first month and decreased to negligible amounts after 3.5 years, remaining low for the rest of the experiment.

The small net increase in total pressure during the experiment was primarily due to the generation of nitrogen and to a lesser extent, hydrogen. Nitrogen slowly increased from 2 to $15 \mathrm{kPa}$ over the first four years of the experiment.

\section{Moisture measurements on unloading}

SSR132A was removed from the heated array and placed in a holder to cool. The lid was removed and replaced with a lid modified to hold a RH sensor. The relative humidity and temperature in the container were measured using a Vaisala HMT330 sensor and readout. No details are available for the time taken to complete the measurements. No moisture measurements were obtained for SSR132 at the termination of the experiment. For SSR132A, the weight loss in the material at termination by LOI- $200{ }^{\circ} \mathrm{C}$ was $0.97 \mathrm{wt} \%$.

The unloading LOI-200 ${ }^{\circ} \mathrm{C}(0.97 \mathrm{wt} \%)$, was $0.38 \mathrm{wt} \%$ greater than the LOI-200 ${ }^{\circ} \mathrm{C}(0.59 \mathrm{wt} \%)$ at loading. This large increase in the LOI is unexplained and is inconsistent with being moisture because the relative humidity at unloading was low.

The relative humidity in reactor SSR132A at unloading was $15.1 \%$. Given this relative humidity, BET theory predicts approximately 0.7 monolayers (ML) or $0.04 \mathrm{wt} \%$ weakly bound water in the reactor (Appendix 4). This corresponds to a reduction of approximately $0.43 \mathrm{wt} \%$ or greater than $90 \%$ of the weakly bound moisture during the experiment. A similar large reduction in moisture was observed in previous reactors and is probably due, in part, to water condensing in the colder region of the reactor plumbing. ${ }^{8}$

Sample unloading and moisture data are summarized in Table 6. 
Table 6. Unloading moisture data summary for SSR132A.

\begin{tabular}{|l|l|c|c|}
\hline & \multicolumn{1}{|c|}{ Parameter } & Value & Units \\
\hline 1 & Unloading Moisture by LOI-200 ${ }^{\circ} \mathrm{C}$ & 0.97 & $\mathrm{wt} \%$ \\
\hline 2 & $\begin{array}{l}\text { Estimated additional strongly bound moisture } \\
\text { of 1.5 ML }\end{array}$ & 0.08 & $\mathrm{wt} \%$ \\
\hline 3 & $\begin{array}{l}\text { Estimated total moisture at unloading from LOI } \\
=\text { Line 1 + Line 2 }\end{array}$ & 1.05 & $\mathrm{wt} \%$ \\
\hline 4 & $\begin{array}{l}\text { Relative Humidity/Temperature in headspace at } \\
\text { unloading }\end{array}$ & $15.1 / 25.9$ & $\mathrm{ML}$ \\
\hline 5 & $\begin{array}{l}\text { Number of monolayers at unloading RH and } \\
\text { temperature using Figure A-1 and c=7. }\end{array}$ & 0.7 & $\mathrm{wt} \%$ \\
\hline 6 & $\begin{array}{l}\text { Mass of weakly bound water (RH) using \# of } \\
\text { MLs in line 5. }\end{array}$ & 0.04 & $\mathrm{wt} \%$ \\
\hline & $\begin{array}{l}\text { Estimated total moisture (RH + 1.5ML strongly } \\
\text { bound) at unloading from RH and temperature } \\
=\text { line 2 + line 6 }\end{array}$ & 0.12 & \\
\hline
\end{tabular}

\section{Corrosion}

Images of the inner buckets of SSR132 and SSR132A are shown in Figure 8. No images of the bottom of the bucket were available.

a)

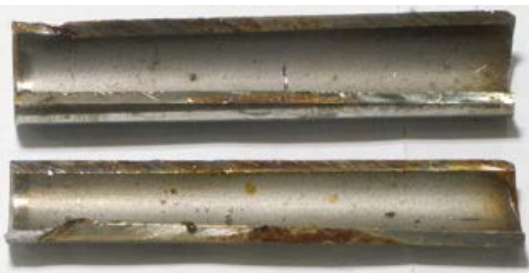
$\operatorname{csR} 132$

c)

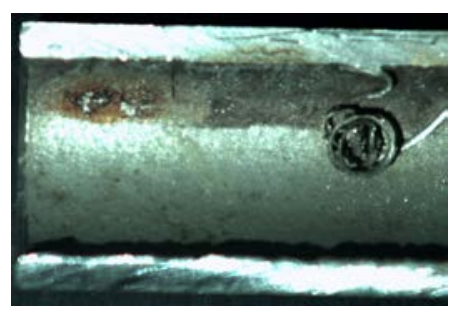

b)
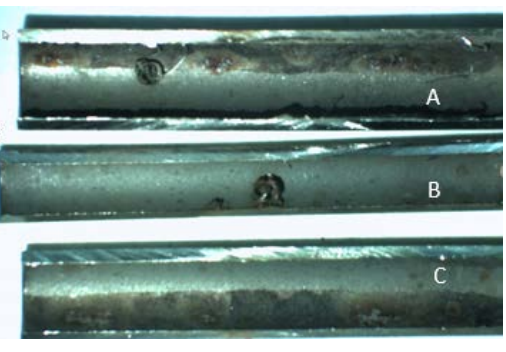

d)

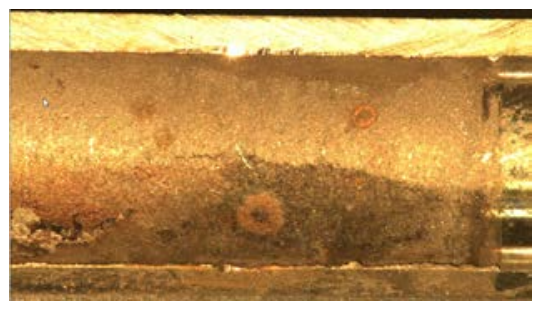

e)

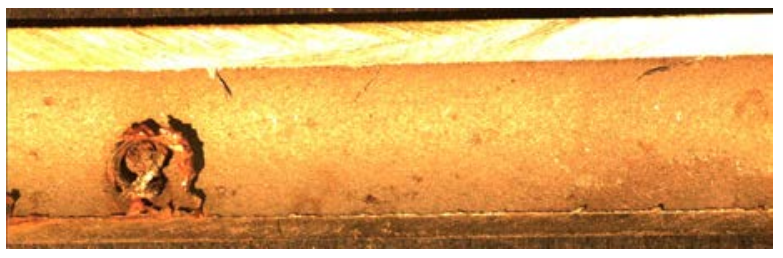

Figure 8. Photographs after unloading: a) inner bucket of SSR132 b) inner bucket of SSR132A c) close up of SSR132A section A d) close up of SSR132A section C and e) close up of SSR132A section B. 
Limited corrosion was observed in the buckets with no clear distinction between the contact and headspace regions. In image a) corrosion is visible on the cut surface of the inner bucket suggesting that the bucket was exposed to a corrosive environment during or after cutting.

\section{Discussion}

A goal of the small-scale surveillance studies is to understand the hydrogen gas generation response of material exposed to moisture over a broad range of materials.

Recommendations on the analysis of hydrogen partial pressure curves include calculations to obtain hydrogen G-values and formation and consumption rate constants assuming that the hydrogen gas is formed and consumed either from radiolysis or from chemical surface reactions. ${ }^{5}$ In order to perform these calculations knowledge of the moisture content of the material during the study and the ionizing radiation dose to the moisture is required. We will first discuss the amount of moisture on the material during the study and use the results as input to the $G\left(\mathrm{H}_{2}\right)$ and rate constant calculations. We will follow those results with a discussion of the observation of other gases.

Unlike plutonium-bearing materials currently stored in 3013 containers throughout the DOE complex, BLO-39-11-14-004 was exposed to the glove box environment for six to eleven years after calcination prior to loading. A significant formation of hydroxyls on the oxide surface is expected after this much time. Gases, such as $\mathrm{CO}_{2}$ or $\mathrm{NOx}$, would also be adsorbed by the surface and come off of the material slowly over time after moisture is added to the system. The presence of these species may alter the gas generation behavior compared with recently calcined (to $950^{\circ} \mathrm{C}$ ) plutonium oxide.

\section{$\mathrm{H}_{2} \mathrm{G}$-value and rate constants}

The formation and consumption of $\mathrm{H}_{2}$ can be represented in a simple scheme as:

$$
\begin{array}{ll}
\mathrm{H}_{2} \mathrm{O} \stackrel{k_{1}}{\rightarrow} \mathrm{H}_{2}+\frac{1}{2} \mathrm{O}_{2} & \text { Eq. } 1 \\
\mathrm{H}_{2}+2 \mathrm{PuO}_{2} \stackrel{k_{2}}{\rightarrow} 2 \mathrm{PuOOH} & \text { Eq. } 2
\end{array}
$$

where the oxygen in Eq. 1 either enters the gas phase or is consumed by the $\mathrm{PuO}_{2}$. Less than $1 \mathrm{kPa}$ of oxygen gas was observed and it was subsequently consumed so both mechanisms occurred. The material present within the sealed container that has the greatest potential to consume $\mathrm{H}_{2}$ is $\mathrm{PuO}_{2}$. The precise nature of the formation and consumption reactions are not known and the product shown in Eq. 2 is for illustration purposes. The important aspect of Eq. 2 is that the $\mathrm{H}_{2}$ forms a species that does not reform $\mathrm{H}_{2}$.

The change in $\mathrm{H}_{2}$ pressure due to the reactions in Eq. 1 and Eq. 2 can be written in differential form as:

$$
\frac{d P_{H 2}}{d t}=k_{1} A(t)-k_{2} P_{H 2} \quad \text { Eq. } 3
$$

where $P_{H 2}$ is the partial pressure of hydrogen, $\mathrm{A}(\mathrm{t})$ is the active water in the reactor involved in hydrogen generation, expressed in units of pressure using the ideal gas law, $t$ is time in days, and 
$\mathrm{k}_{1}$ and $\mathrm{k}_{2}$ are the first-order rate constants for the formation and consumption of hydrogen in days ${ }^{-}$

1. The model predicts exponential decay of the active water, A(t), with time as shown in Eq. 4.

$$
A_{\mathrm{H}_{2} \mathrm{O}}(t)=A_{0} e^{-k_{1} t} \quad \text { Eq. } 4
$$

where $A_{0}$ is the amount of active water at $\mathrm{t}=0$. Substituting Eq. 4 into Eq. 3 yields equation Eq. 5 :

$$
\frac{d P_{H 2}}{d t}=k_{1} A_{0} e^{-k_{1} t}-k_{2} P_{H 2} \quad \text { Eq. } 5
$$

The initial rate of hydrogen generation is calculated by evaluating Eq. 5 at $\mathrm{t}=0$ assuming $P_{\mathrm{H}_{2}}$ is zero at $\mathrm{t}=0$. The initial hydrogen generation rate is equal to $\mathrm{k}_{1} \mathrm{~A}_{0}$ (Appendix 6.)

Eq. 5 can be integrated to yield Eq. 6, again assuming $P_{H_{2}}$ is zero at $\mathrm{t}=0$.

$$
P_{H_{2}}(t)=\frac{A_{0} k_{1}}{k_{2}-k_{1}}\left(e^{-k_{1} t}-e^{-k_{2} t}\right) \text { Eq. } 6
$$

The expression for the maximum hydrogen pressure of a system behaving according to Eq. 6 is shown in Eq. 7 where $\mathrm{K}=\mathrm{k}_{2} / \mathrm{k}_{1}$.

$$
P_{\max }=A_{0}\left(K^{K /(1-K)}\right) \text { Eq. } 7
$$

The hydrogen partial pressure versus time observations for SSR132A, fit to Eq. 6, is shown in Figure 9. (Due to the known leak in the system, data from SSR132 was not fit.). The fit to the limited number of data points in Figure 9 is poor suggesting that either the uncertainty in the data is larger than reported in Appendix 1 or that the model is not sufficiently complex. The plateau at long times suggests that a reaction that reforms hydrogen is occurring, resulting in an equilibrium partial pressure of $\mathrm{H}_{2}$. Studies of BLO-39-11-14-004 material that may clarify the $\mathrm{H}_{2}$ behavior with time are being carried out and will be addressed in a later report. 


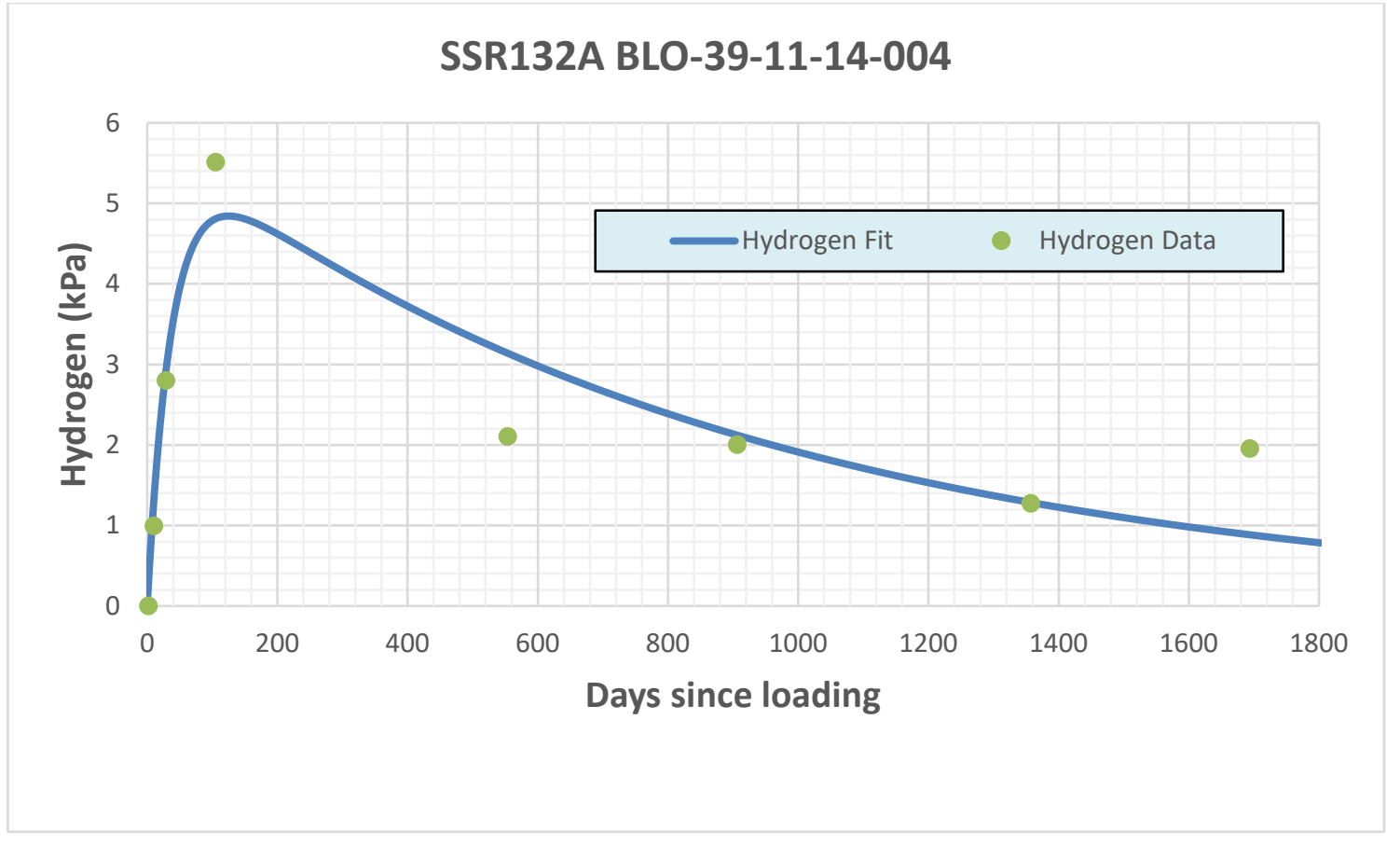

Figure 9. The hydrogen partial pressure and the fit to Equation 6, or first order formation and first order consumption reaction with an $\mathrm{r}^{2}$ coefficient of 0.85 .

The values for the fit parameters yielding the curves in Figure 9 along with the standard error in the parameters are given in Table 7. The function reached a maximum of $4.9 \mathrm{kPa}$ at 116 days. The initial rate of hydrogen generation calculated from these parameters are also reported in Table 7. The fit of the initial points is very good and the estimate of the initial rate, the product of $k_{1}$ and $A_{0}$, is minimally affected by the poor fit at long times. However, there is considerably more uncertainty in the individual values of $\mathrm{k}_{1}$ and $\mathrm{A}_{0}$.

Table 7. The fit parameters based on the reaction model, standard errors and initial rate from the hydrogen generation data for SSR132A at $55^{\circ} \mathrm{C}$ from Eq 6.

\begin{tabular}{|c|c|c|c|c|}
\hline $\begin{array}{c}\text { Small-scale } \\
\text { Surveillance sample ID }\end{array}$ & $A_{0}$ & $\begin{array}{c}k_{1} \\
\left(\text { day }^{-1}\right)\end{array}$ & $\begin{array}{c}k_{2} \\
\left(\text { day }^{-1}\right)\end{array}$ & $\begin{array}{c}\text { Initial Rate }(k \text { Pa/day) } \\
\left(\mathrm{k}_{1} \mathrm{~A}_{0}\right)\end{array}$ \\
\hline SSR132A & 148 & 0.001099 & 0.296 & 0.163 \\
\hline Standard Error & 82 & 0.00034 & 0.014 & \\
\hline
\end{tabular}

The initial active water from the fit based on the reaction model corresponds to $0.2 \mathrm{wt} \%$ or approximately $33 \%$ of the initial water loaded on the sample. A plot of $A(t)$, the estimated wt $\%$ of water active in hydrogen formation (A) remaining in the system, as a function of time using Eq. 4 is plotted in Figure 10 below. 


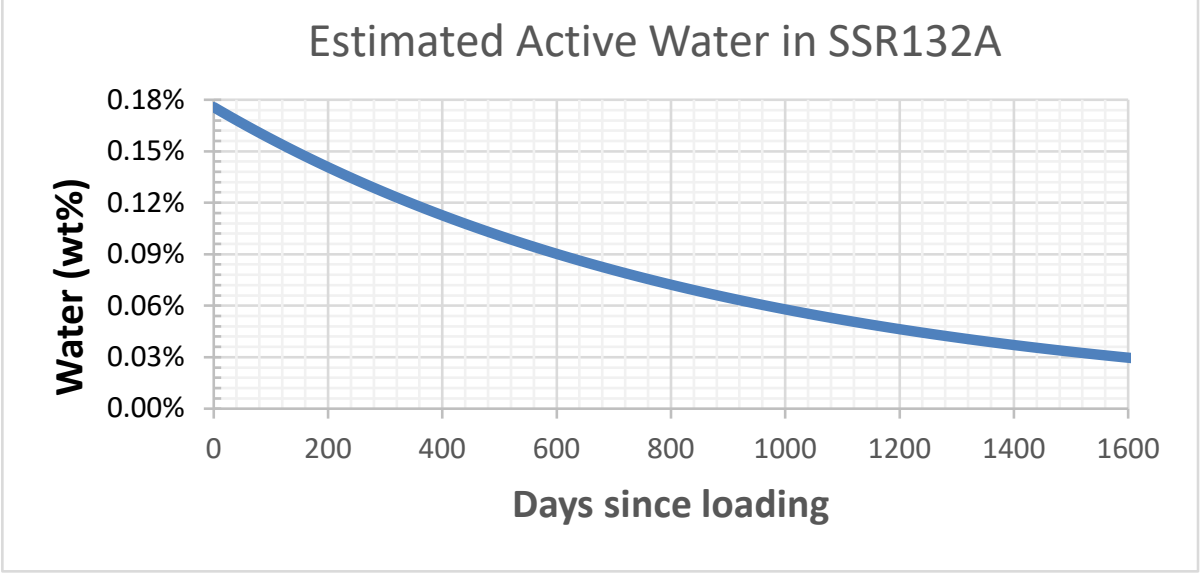

Figure 10. Graph of the estimated active water, A(t), in SSR132A as a function of time, where $\mathrm{A}_{0}$ is expressed in terms of $\mathrm{wt} \%$ of water.

\section{Estimation of the amount of moisture on the material during the gas generation study} Moisture adsorbed on high-purity plutonium dioxide such as BLO-39-11-14-004 is thought to exist as physisorbed (weakly bound) water that behaves according to BET theory ${ }^{9}$ and as chemisorbed (strongly bound) water with very low chemical activity (very low water vapor pressure). The latter water can be described as surface hydroxyls and is removed from the plutonium dioxide surface only at high temperatures. In order to use BET theory to estimate the amount of physisorbed and chemisorbed water on the material during the experiment, the SSA, the amount of water in a monolayer, and the RH are needed. RH data was only available at the termination of the experiment.

The difference between the best estimate of the amount of water in SSR132A when the material was loaded (0.015 $\mathrm{g}$ from TGA) and unloaded (0.003 $\mathrm{g}$ from $\mathrm{RH}), 0.012 \mathrm{~g}$, is much greater than the amount of water that produced $\mathrm{H}_{2}(0.0002 \mathrm{~g})$ plus the amount of water that would be in the gas phase at unloading (0.00002 g), $0.0002 \mathrm{~g}$. A gradual conversion of physisorbed water to chemisorbed water (hydroxyls) during the experiment would contribute to lower measured moisture content at the termination of the experiment than at the beginning because more water would be inaccessible to the LOI-200 ${ }^{\circ} \mathrm{C}$ measurement. The conversion of weakly-bound water to strongly-bound water over time is expected to be less than 1.0 monolayers of water, which corresponds to approximately $0.001 \mathrm{~g}$ for this sample, much less than the difference between the moisture at loading and unloading. ${ }^{10,11}$

The additional difference is probably due to water condensing in the colder region of the reactor plumbing. ${ }^{11}$ During the gas generation study, the condensed moisture in the cold region of the plumbing is located at a sufficient distance from the material that the radiation dose it receives is orders of magnitude smaller than the radiation dose the water associated with the material receives. This water is NOT expected to contribute to gas generation and would result in a low value for $\mathrm{G}\left(\mathrm{H}_{2}\right)$ in $\mathrm{G}$-value calculations.

Moisture at loading (TGA) overestimates the water receiving radiation dose resulting in gas generation since it includes chemisorbed water and water condensed on the cold region of the reactor. Results based on loading moisture are expected to underestimate the value for $\mathrm{G}\left(\mathrm{H}_{2}\right)$. 
Moisture at unloading underestimates the water receiving radiation dose resulting in gas generation calculations since it does not include water that reacted during the course of the experiment. Results based on unloading moisture are expected to overestimate the value for $\mathrm{G}\left(\mathrm{H}_{2}\right)$. Table 8 summarizes estimates of the amount of water on the material at loading and unloading, initial and reacted based on the reaction model, condensed on the piping, in the gas phase, and decomposed to form $\mathrm{H}_{2}$ expressed as weight percent, moles, grams, and monolayers. The initial active water from the fit to the reaction model may provide the best estimate of the water involved in hydrogen generation for calculating $\mathrm{G}(\mathrm{H} 2)$.

Table 8. The amount of water adsorbed on the material, in the gas phase, and decomposed to form $\mathrm{H}_{2}$ expressed as moles, grams, and monolayers. The mass of water in a monolayer is $0.0013 \mathrm{~g}$. Calculations use SSA $=2.4 \mathrm{~m}^{2} \mathrm{~g}^{-1}, \mathrm{~m}_{\text {mat }}=2.51 \mathrm{~g}$ and $\mathrm{V}_{\text {gas }}=5.093 \mathrm{~cm}^{3}$. The amount of strongly bound chemisorbed water on the material was assumed to be 1.5 monolayers wt\% at all times.

\begin{tabular}{|c|c|c|c|c|}
\hline \multirow[t]{2}{*}{ Water Source } & \multicolumn{4}{|c|}{ Amount of Water } \\
\hline & wt\% & g & moles & monolayers \\
\hline & 0.053 & 0.0013 & $7.4 \times 10^{-5}$ & 1 \\
\hline $\begin{array}{l}\text { In gas at } 25.1^{0} \mathrm{C} \text { and } 100 \% \mathrm{RH} \\
(3.2 \mathrm{kPa})\end{array}$ & 0.0045 & 0.00011 & $5.9 \times 10^{-6}$ & 0.08 (equivalent) \\
\hline $\begin{array}{l}\text { In gas at } 55^{0} \mathrm{C} \text { and } 100 \% \mathrm{RH} \\
(15.75 \mathrm{kPa})\end{array}$ & 0.022 & 0.00053 & $2.9 \times 10^{-5}$ & 0.4 (equivalent) \\
\hline $\begin{array}{l}\text { On material at loading: weakly } \\
+ \text { strongly bound (TGA) }\end{array}$ & 0.59 & 0.015 & $8.3 \times 10^{-4}$ & 11.1 \\
\hline $\begin{array}{l}\text { Initial active water based on } \\
\text { reaction model } \quad\left(\mathrm{A}_{0}=148 \mathrm{kPa}\right)\end{array}$ & 0.20 & 0.0049 & $2.8 \times 10^{-4}$ & 3.8 \\
\hline $\begin{array}{l}\text { Reacted to produce } \mathrm{H}_{2} \text { based on } \\
\text { reaction model (Figure 10) }\end{array}$ & 0.166 & 0.0042 & $2.3 \times 10^{-4}$ & 3.1 \\
\hline $\begin{array}{l}\text { Reacted to produce max } \mathrm{H}_{2} \text { in } \\
\text { gas at } 55^{0} \mathrm{C}(5.5 \mathrm{kPa})\end{array}$ & 0.0074 & 0.00018 & $1.0 \times 10^{-5}$ & 0.14 (equivalent) \\
\hline $\begin{array}{l}\text { In gas at unloading, } 25.1{ }^{0} \mathrm{C} \text { and } \\
15.1 \% \mathrm{RH}(0.5 \mathrm{kPa})\end{array}$ & 0.00069 & $1.7 \times 10^{-5}$ & $9.6 \times 10^{-7}$ & $\begin{array}{c}0.013 \\
\text { (equivalent) }\end{array}$ \\
\hline $\begin{array}{l}\text { Presumed condensed on piping } \\
\text { and effectively removed from } \\
\text { the system = (Loading(TGA) - } \\
\text { Unload(RH) - reacted water - } \\
\text { strongly bound (1.5ML) }\end{array}$ & 0.31 & 0.0078 & $4.3 \times 10^{-4}$ & 5.8 \\
\hline
\end{tabular}




\begin{tabular}{|l|c|c|c|c|}
\hline Water Source & \multicolumn{3}{|c|}{ Amount of Water } \\
\hline & wt\% & $\mathrm{g}$ & moles & monolayers \\
\hline $\begin{array}{l}\text { Presumed condensed on piping } \\
\text { and effectively removed from } \\
\text { the system = (Loading(TGA)- } \\
\begin{array}{l}\text { Unload(RH)-max H2-strongly } \\
\text { bound(1.5ML) }\end{array}\end{array}$ & 0.46 & 0.012 & $6.5 \times 10^{-4}$ & 8.8 \\
\hline $\begin{array}{l}\text { On material at unloading: } \\
\text { weakly bound (LOI) }\end{array}$ & \multicolumn{3}{|c|}{ Results not included: Unexplained LOI result } \\
\hline $\begin{array}{l}\text { On material at unloading: } \\
\text { weakly bound (RH) }\end{array}$ & 0.04 & 0.0009 & $5 \times 10^{-5}$ & 0.7 \\
\hline $\begin{array}{l}\text { On material at unloading: } \\
\text { weakly bound (LOI) + strongly } \\
\text { (1.5 ML) }\end{array}$ & \multicolumn{3}{|c|}{ Results not included: Unexplained LOI result } \\
\hline $\begin{array}{l}\text { On material at unloading: } \\
\text { weakly (RH)+strongly (1.5 ML) }\end{array}$ & 0.12 & 0.0029 & 0.00016 & 2.2 \\
\hline
\end{tabular}

(Note: Additional moisture could have been consumed in formation of the corrosion products such as iron hydroxide)

$\mathrm{A}_{0}, \mathrm{k}_{1}$, and $\mathrm{k}_{2}$ are used to calculate $G\left(H_{2}\right)$ and the rate constants for the hydrogen formation and consumption surface reactions using formulas in Appendix 6. Because of the uncertainty in determining the amount of water involved in the hydrogen generation, several values are used for the variable $\mathrm{m}_{\mathrm{H} 2 \mathrm{O}}$. The stopping power ratio for BLO-39-11-14-004 material, $\frac{s_{\mathrm{H}_{2} \mathrm{o}}}{\boldsymbol{s}_{\text {mat }}}$, is 3.63 (Appendix 5). Results for $\mathrm{G}\left(\mathrm{H}_{2}\right)$ using the various choices for the amount of water active in producing $\mathrm{H}_{2}$ using equations from Appendix 6, are reported in Table 9. It is expected that the total water at loading overestimates the amount of water involved in hydrogen generation since in includes strongly bound water (hydroxyls) that is not expected to react as well as water that condensed in the cold part of the piping. Results based on total water at loading bound the lower value for $\mathrm{G}(\mathrm{H} 2)$. 
Table 9. $\mathrm{G}\left(\mathrm{H}_{2}\right)$ calculated from reaction parameters and estimated moisture content using equation A6-4 in Appendix 6 assuming radiolytic decomposition of water to form $\mathrm{H}_{2}$.

\begin{tabular}{|c|c|}
\hline \multirow{2}{*}{$\begin{array}{c}\text { Source for the amount of water receiving radiation dose } \\
\text { Total water at loading (TGA) }\end{array}$} & $G\left(\mathrm{H}_{2}\right)$ \\
\hline molecules $100 \mathrm{eV}^{-1}$ \\
\hline Active water based on reaction model $\left(\mathrm{A}_{0}\right)$ & 0.045 \\
\hline Water reacted to produce max $\mathrm{P}_{\mathrm{H} 2}$ in gas at $55^{\circ} \mathrm{C}$ & 0.134 \\
\hline Water on material at unloading: weakly bound $(\mathrm{RH})$ & 3.610 \\
\hline Water on material at unloading: weakly bound $(\mathrm{RH})+1.5 \mathrm{ML}$ & 0.72 \\
\hline
\end{tabular}

The equations to obtain the rates and rate constants for the surface reactions in Appendix 6 are not dependent on the amount of water and only a single value for each is given in Table 10 .

Table 10. Rate constants calculated from the reaction parameters and the estimated moisture content assuming surface catalyzed decomposition of water to form $\mathrm{H}_{2}$.

\begin{tabular}{|c|c|c|c|}
\hline Variable & Eq. in Appendix 6 & Value & Units \\
\hline $\mathrm{k}_{\text {for }}$ & $\mathrm{A} 6-5$ & $2.12 \mathrm{E}+12$ & molecules s \\
\hline $\mathrm{k}_{\text {con }}$ & $\mathrm{A} 6-6$ & $3.85 \mathrm{E}+11$ & molecules s$^{-1} \mathrm{kPa}^{-1}$ \\
\hline $\mathrm{R}_{\text {for }}$ & $\mathrm{A} 6-8$ & 2.11 & nanomoles $\mathrm{m}^{-2} \mathrm{hr}^{-1}$ \\
\hline $\mathrm{R}_{\text {con }}$ & $\mathrm{A} 6-9$ & 0.38 & nanomoles $\mathrm{m}^{-2} \mathrm{hr}^{-1}$ \\
\hline
\end{tabular}

Figure 11 compares the $\mathrm{G}\left(\mathrm{H}_{2}\right)$ values determined in this study with those reported previously. ${ }^{12}$ 


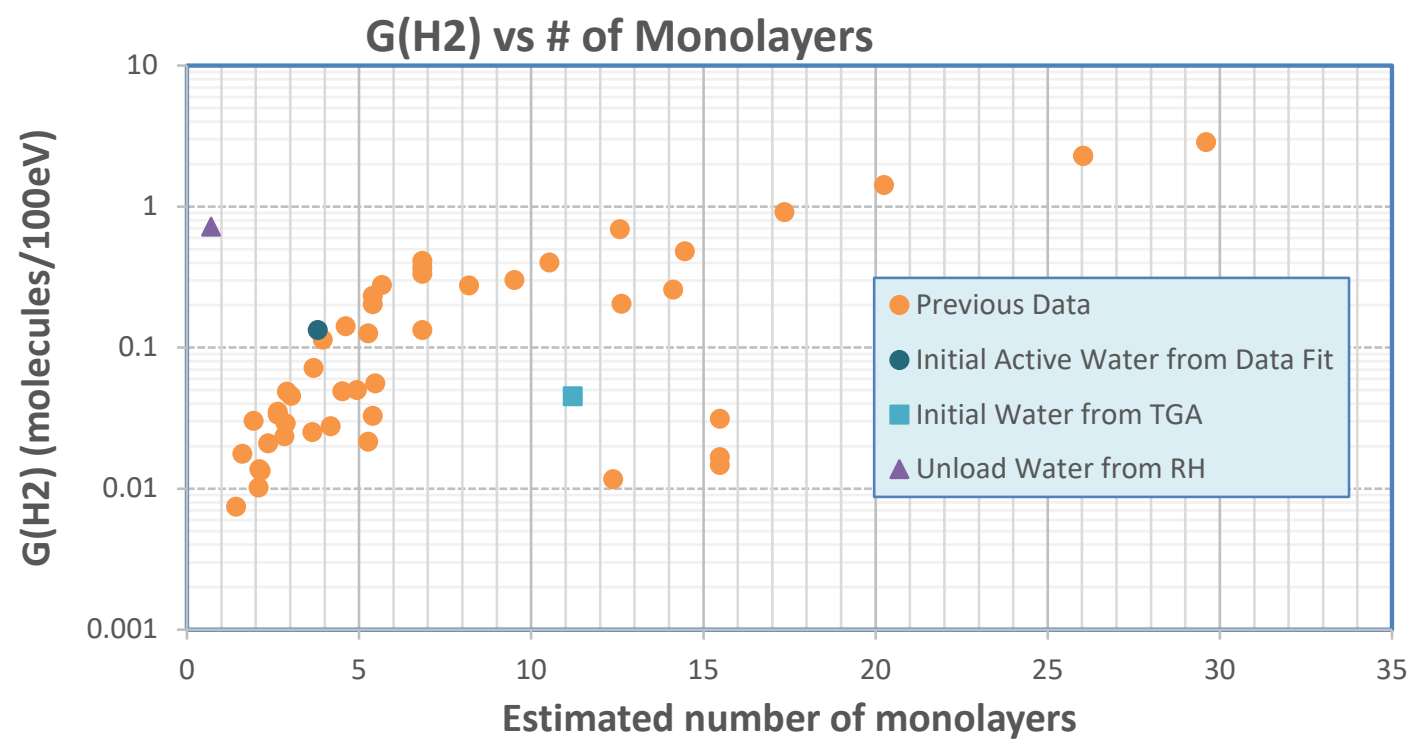

Figure 11. Comparison of calculated $\mathrm{G}\left(\mathrm{H}_{2}\right)$ plotted against the number of calculated water monolayers determined in this study with those from previous research.

\section{Behavior of $\mathrm{CO}_{2}$ and $\mathrm{NO}_{2}$ for SSR132A}

While $4 \times 10^{-5}$ moles of carbon dioxide were detected by TGA-MS on the sample at loading an order of magnitude less $\mathrm{CO}_{2}$ was observed in the headspace during the experiment. In contrast, no nitrogen oxide was observed in the TGA but $3 \times 10^{-5}$ moles of $\mathrm{N}_{2}$ were observed in the gas phase. (The compounds actually bound to the plutonium dioxide surface could have been any of the general forms COx and NOx). Results are summarized in Table 11.

Table 11. Amount of nitrogen species detected on the surface prior to loading compared to the amount detected in the gas phase.

\begin{tabular}{|c|c|c|c|}
\hline & $\begin{array}{c}\mathbf{C O}_{2} \\
\text { (moles) }\end{array}$ & $\begin{array}{c}\mathbf{N O}_{2} \\
\text { (moles) }\end{array}$ & $\begin{array}{c}\mathbf{N}_{2} \\
\text { (moles) }\end{array}$ \\
\hline Sample (Loading-TGA-MS) & $4 \times 10^{-5}$ & 0 & Not measured \\
\hline $\begin{array}{c}\text { Max Detected in Head Space over } \\
\text { duration of experiment (GC) }\end{array}$ & $3 \times 10^{-6}$ & Not measured & $3 \times 10^{-5}$ \\
\hline
\end{tabular}

Prior to loading the sample in the small-scale reactor, the plutonium dioxide powder was exposed to air for eleven years (nitrogen and oxygen with small amounts of water and carbon dioxide). The sample was placed in a helium atmosphere within the small-scale reactor with a large partial pressure of water. A possible explantion for $\mathrm{CO}_{2}$ and $\mathrm{N}_{2}$ observed in the headspace is that the water displaced chemically adsorbed $\mathrm{CO}_{2}$ and $\mathrm{N}_{2}$ formed from the $\mathrm{NOx}$. The $\mathrm{CO}_{2}$ detected in the headspace during the experiment (Figure 7) was an order of magnitude less than the CO on the surface available. In contrast, significant $\mathrm{N}_{2}$ was detected which is inconsistent with no NO observed in the TGA-MS and therefore no NOx on the surface available to form $\mathrm{N}_{2}$ (Figure 5). The observation of $\mathrm{CO}_{2}$ 
and $\mathrm{N}_{2}$ produced in this high-purity plutonium dioxide materials exposed to air is consistent with other high-purity oxides, however, the magnitude of the partial pressure observed varies with material. ${ }^{8,12}$

\section{Behavior of He}

The alpha decay of the Pu and Am creates He, which may escape the oxide into the gas phase. The amount of He created depends upon the mass of the material and the rate of decay of the various isotopes. The rate of He evolution and amount evolved as a function of time are shown in Figure 3.

The amount of He created due to alpha decay over the time the material was in SSR132A is estimated to be $9.8 \times 10^{-6}$ moles for the $2.5 \mathrm{~g}$ sample. This amount of He would result in a gas pressure increase of $5.9 \mathrm{kPa}$ in the $5.1 \mathrm{~cm}^{3}$ of gas volume and gas temperature of 328 $\mathrm{K}$, if all the He was released into the gas phase. Instead the He pressure declined by approximately $5 \mathrm{kPa}$, which is $\sim 0.6 \mathrm{kPa}$ less than the decline expected due to the 8 gas samplings $(5.6 \mathrm{kPa})$. Thus, it appears that $0.6 \mathrm{kPa}$ or $10 \%$ of the predicted $5.9 \mathrm{kPa}$ of generated He was released into the gas phase. This analysis does not account for any leaks in the system or the large uncertainties associated with the He gas measurements.

\section{Conclusions}

The MIS item BLO-39-11-14-004 was entered into surveillance in June of 2008 and removed from surveillance in January of 2013. The initial amount of water involved in gas generation was estimated to be $0.12 \mathrm{wt} \%$ based on the reaction model. The gas generation was dominated by $\mathrm{H}_{2}$ and $\mathrm{N}_{2}$. Hydrogen was generated to a maximum partial pressure of $5.5 \mathrm{kPa}$ but declined after reaching this maximum after approximately 105 days. Oxygen was generated to a maximum partial pressure of $0.9 \mathrm{kPa}$ and was then consumed, reaching a final equilibrium partial pressure of approximately $0.1 \mathrm{kPa}$. Limited corrosion was observed in the reactor buckets with no clear distinction between the contact and headspace regions.

\section{Acknowledgements}

Funding for this work was provided to the MIS Program by the Assistant Manager for Nuclear Materials Stabilization, Savannah River Operations Office, Department of Energy's Office of Environmental Management. 


\section{References}

1. U. S. Department of Energy, Stabilization, Packaging, and Storage of Plutonium-Bearing Materials. U.S. Department of Energy: Washingon, D.C., 2012.

2. Narlesky, J. E.; Peppers, L. G.; Friday, G. P. Complex-Wide Representation of Material Packaged in 3013 Containers; LA-UR-14396; Los Alamos National Laboratory: Los Alamos, NM, 2009.

3. Narlesky, J. E. P., L. G.; Friday, G. P. Complex-Wide Representation of Material Packaged in 3013 Containers; LA-UR-14396; Los Alamos National Laboratory: Los Alamos, NM, 2009.

4. Veirs, D. K.; Worl, L. A.; Harradine, D. M.; Martinez, M. A.; Lillard, S.; Schwartz, D. S.; Puglisi, C. V.; Padilla, D. D.; Carrillo, A.; McInroy, R. E.; Montoya, A. R. Gas generation and corrosion in salt-containing impure plutonium oxide materials: Initial results for ARF-102-85-223; LA-UR-041788; Los Alamos National Laboratory: Los Alamos, NM, 2004.

5. Veirs, D. K.; Berg, J. M.; Stroud, M. A. Obtaining G-values and rate constants from MIS data; LAUR-17-23787; Los Alamos National Laboratory: Los Alamos, NM, 2017.

6. Veirs, D. K.; Berg, J. M.; Crowder, M. L. The effect of plutonium dioxide water surface coverage on the generation of hydrogen and oxygen; LA-UR-12-22377; Los Alamos National Laboratory: Los Alamos, NM, 2012.

7. Worl, L., Berg, John, Bielinberg, Patricia, Carrillo, Alex, Martinez, Max, Montoya, Adam, Veirs, Kirk, Puglisi, Charles, Rademacher, Dave, Schwartz, Dan, Harradine, David, McInroy, Rhonda, Hill, Dallas, Prenger, Coyne, Steward, Jim Shelf Life Surveillance for PuO2 Bearing Materials FY04 Second Quarterly Report; Los Alamos National Laboratory: 2004.

8. Veirs, D. K., Stroud, M.A., Berg, J., Narlesky, J. Worl, L., Martinez, M.,. Carillo, A. MIS HighPurity Plutonium Oxide Metal Oxidation PRoduct TS707001 (SSR123): Final Report; LA-UR-1727172; Los Alamos National Laboratory: Losa Alamos, NM, 2017.

9. Brunauer, S.; Emmett, P. H.; Teller, E., Adsorption of Gases in Multimolecular Layers. Journal of the American Chemical Society 1938, 60.

10. Veirs, D. K.; Berg, J. M.; Hill, D. D.; Harradine, D. M.; Narlesky, J. E.; Romero, E. L.; Trujillo, L.; Wilson, K. V. Water radiolysis on plutonium dioxide: Initial results identifying a threshold relative humidity for oxygen gas generation; LA-UR-12-26423; Los Alamos National Laboratory: Los Alamos, NM, 2012.

11. Veirs, D. K. S., M. A.; Martinez, M. ; Carrillo, A.; Berg, J.; Narlesky, J.; Worl, L. MIS High-Purity Plutonium Oxide Metal Oxidation Product TS707001 (SSR123): Final Report; LA-UR-17-27172; Los Alamos National Laboratory: Los Alamos, NM, 2017.

12. Veirs, D. K., Stroud, M.A., Berg, J., Narlesky, J. Worl, L., Martinez, M.,. Carillo, A. MIS HighPurity Plutonium Oxide Hydride Product 5501579 (SSR124): Final Report LA-UR-18-20970; Los Alamos National Laboratory: Los Alamos, NM, 2018.

13. Haschke, J. M.; Ricketts, T. E., Adsorption of water on plutonium dioxide. Journal of Alloys and Compounds 1997, 252, 148-156.

14. Paffett, M. T.; Kelly, D.; Joyce, S. A.; Morris, J.; Veirs, K., A critical examination of the thermodynamics of water adsorption on actinide oxide surfaces. Journal of Nuclear Materials 2003, 322, 45-56.

15. (a) Haschke, J. M.; Allen, T. H.; Morales, L. A., Reaction of Plutonium Dioxide with Water: Formation and Properties of $\mathrm{PuO}_{2+x}$. Science 2000, 287, 285-286; (b) Haschke, J. M.; Allen, T. H.; Morales, L. A., Reactions of plutonium dioxide with water and hydrogen-oxygen mixtures: Mechanisms for corrosion of uranium and plutonium. Journal of Alloys and Compounds 2001, 314, 78-91. 


\section{Appendix 1, Gas Generation Partial Pressure Data and Uncertainties in kPa}

Note: Total pressure values used to determine partial pressures were reduced by $4 \mathrm{kPa}$ to correct for the estimated partial pressure of water vapor. Partial pressures were corrected for variation in the sensitivity of the GC with time. The average manifold background pressure was subtracted from the partial pressures.

\section{SSR132 (Reactor leaked)}

\begin{tabular}{|c|c|c|c|c|c|c|c|c|c|c|c|c|}
\hline Date & $1 / 8 / 2004$ & $2 / 11 / 2004$ & $2 / 17 / 2004$ & $2 / 18 / 2004$ & $2 / 26 / 2004$ & $2 / 26 / 2004$ & $6 / 9 / 2004$ & $1 / 24 / 2005$ & 8/30/2005 & 4/19/2006 & $10 / 23 / 2006$ & $1 / 25 / 2007$ \\
\hline Days & 31.0 & 65.0 & 71.0 & 72.0 & 80.0 & 80.0 & 184.0 & 413.0 & 631.0 & 863.0 & 1050.0 & 1144.0 \\
\hline $\mathrm{CO}_{2}$ & 0.0 & 0.6 & 0.0 & 0.1 & 0.0 & 0.6 & 1.0 & 0.4 & 0.1 & 0.1 & 0.0 & 0.0 \\
\hline $\mathrm{N}_{2} \mathrm{O}$ & 0.0 & 0.3 & 0.0 & 0.0 & 0.1 & 0.1 & 0.3 & 0.4 & 0.4 & 0.3 & 0.5 & 0.0 \\
\hline $\mathrm{He}$ & 77.6 & 45.2 & 0.4 & 0.4 & 0.5 & 72.5 & 73.6 & 67.5 & 60.6 & 57.7 & 44.3 & 77.6 \\
\hline $\mathrm{H}_{2}$ & 0.0 & 0.8 & 0.0 & 0.1 & 0.5 & 0.3 & 1.1 & 0.6 & 0.4 & 0.3 & 0.3 & 0.0 \\
\hline $\mathrm{O}_{2}$ & 0.1 & 2.7 & 1.2 & 1.3 & 1.3 & 2.2 & 3.4 & 7.2 & 8.9 & 8.2 & 7.7 & 0.1 \\
\hline $\mathrm{N}_{2}$ & 0.4 & 11.3 & 4.1 & 4.5 & 5.3 & 8.2 & 8.7 & 12.6 & 15.6 & 16.2 & 19.3 & 0.4 \\
\hline $\mathrm{CH}_{4}$ & 0.0 & 0.0 & 0.0 & 0.0 & 0.0 & 0.0 & 0.0 & 0.0 & 0.0 & 0.0 & 0.0 & 0.0 \\
\hline $\mathrm{CO}$ & 0.0 & 0.2 & 0.0 & 0.0 & 0.0 & 0.0 & 0.3 & 0.0 & 0.0 & 0.0 & 0.0 & 0.0 \\
\hline $\mathrm{H}_{2} \mathrm{O}$ (estimate) & 4 & 4 & 4 & 4 & 4 & 4 & 4 & 4 & 4 & 4 & 4 & 4 \\
\hline SUM Check & 82.10 & 65.10 & 9.67 & 10.30 & 11.75 & 87.97 & 92.49 & 92.68 & 90.08 & 86.88 & 76.12 & 82.1 \\
\hline
\end{tabular}




\section{Appendix 1, Gas Generation Partial Pressure Data and Uncertainties in kPa (continued)}

\section{Uncertainties}

Note: The uncertainties reported here are calculated from the uncertainties associated with the calibration of the GC and the quantification of the peak area of an observed GC peak. Additional uncertainties that are unrelated to the GC and which are variable in time such as minor leaks in the gas manifold are not reported. Thus, the actual uncertainty in the partial pressures of the gases are likely to be somewhat larger than reported.

\begin{tabular}{|c|c|c|c|c|c|c|c|c|c|c|c|c|}
\hline Date & $1 / 8 / 2004$ & $2 / 11 / 2004$ & $2 / 17 / 2004$ & $2 / 18 / 2004$ & $2 / 26 / 2004$ & $2 / 26 / 2004$ & $6 / 9 / 2004$ & $1 / 24 / 2005$ & 8/30/2005 & 4/19/2006 & 10/23/2006 & $1 / 25 / 2007$ \\
\hline Days & 31.0 & 65.0 & 71.0 & 72.0 & 80.0 & 80.0 & 184.0 & 413.0 & 631.0 & 863.0 & 1050.0 & 1144.0 \\
\hline $\mathrm{CO}_{2}$ & 0.00 & 0.03 & 0.01 & 0.02 & 0.01 & 0.03 & 0.04 & 0.02 & 0.01 & 0.01 & 0.00 & 0.01 \\
\hline $\mathrm{N}_{2} \mathrm{O}$ & 0.00 & 0.02 & 0.00 & 0.01 & 0.02 & 0.02 & 0.02 & 0.02 & 0.02 & 0.02 & 0.03 & 0.02 \\
\hline $\mathrm{He}$ & 1.60 & 0.95 & 0.02 & 0.02 & 0.02 & 1.49 & 1.52 & 1.39 & 1.26 & 1.20 & 0.93 & 1.05 \\
\hline $\mathrm{H}_{2}$ & 0.00 & 0.02 & 0.00 & 0.00 & 0.02 & 0.01 & 0.03 & 0.02 & 0.01 & 0.01 & 0.01 & 0.01 \\
\hline $\mathrm{O}_{2}$ & 0.01 & 0.08 & 0.06 & 0.06 & 0.07 & 0.07 & 0.10 & 0.18 & 0.22 & 0.20 & 0.19 & 0.15 \\
\hline $\mathrm{N}_{2}$ & 0.02 & 0.26 & 0.12 & 0.12 & 0.14 & 0.21 & 0.21 & 0.29 & 0.35 & 0.36 & 0.43 & 0.37 \\
\hline $\mathrm{CH}_{4}$ & 0.00 & 0.00 & 0.00 & 0.00 & 0.00 & 0.00 & 0.00 & 0.00 & 0.00 & 0.00 & 0.00 & 0.00 \\
\hline $\mathrm{CO}$ & 0.00 & 0.25 & 0.00 & 0.00 & 0.00 & 0.00 & 0.31 & 0.00 & 0.01 & & & \\
\hline
\end{tabular}


Appendix 1, Gas Generation Partial Pressure Data and Uncertainties in kPa (continued)

SSR132A

\begin{tabular}{|c|c|c|c|c|c|c|c|c|}
\hline Date & $6 / 11 / 2008$ & 6/19/2008 & 7/8/2008 & $9 / 22 / 2008$ & $12 / 15 / 2009$ & $12 / 2 / 2010$ & $2 / 26 / 2012$ & $1 / 28 / 2013$ \\
\hline Days & 0 & 8 & 27 & 103 & 552 & 904 & 1355 & 1692 \\
\hline $\mathrm{CO}_{2}$ & 0.0 & 0.4 & 1.3 & 2.2 & 0.8 & 0.4 & 0.0 & 0.0 \\
\hline $\mathrm{N}_{2} \mathrm{O}$ & 0.0 & 0.2 & 0.4 & 0.4 & 0.5 & 0.6 & 0.0 & 0.7 \\
\hline $\mathrm{He}$ & 78.1 & 73.8 & 70.8 & 68.3 & 68.2 & 72.7 & 70.2 & 72.3 \\
\hline $\mathrm{H}_{2}$ & 0.0 & 1.0 & 2.8 & 5.5 & 2.1 & 2.0 & 1.3 & 2.0 \\
\hline $\mathrm{O}_{2}$ & 0.7 & 0.7 & 0.9 & 0.9 & 0.8 & 0.3 & 0.0 & 0.2 \\
\hline $\mathrm{N}_{2}$ & 2.7 & 2.6 & 4.1 & 6.4 & 11.8 & 11.2 & 16.6 & 13.3 \\
\hline $\mathrm{CH}_{4}$ & 0.0 & 0.0 & 0.0 & 0.0 & 0.0 & 0.0 & 0.0 & 0.0 \\
\hline $\mathrm{CO}$ & 0.0 & 0.0 & 0.0 & 0.0 & 0.0 & 0.0 & 0.0 & 0.0 \\
\hline $\mathrm{H}_{2} \mathrm{O}$ estimate & 4 & 4 & 4 & 4 & 4 & 4 & 4 & 4 \\
\hline SUM Check & 85.6 & 82.8 & 84.3 & 87.8 & 88.3 & 91.1 & 92.1 & 92.4 \\
\hline
\end{tabular}

Uncertainties

\begin{tabular}{|c|c|c|c|c|c|c|c|c|}
\hline Date & $6 / 11 / 2008$ & $6 / 19 / 2008$ & 7/8/2008 & $9 / 22 / 2008$ & $12 / 15 / 2009$ & $12 / 2 / 2010$ & $2 / 26 / 2012$ & $1 / 28 / 2013$ \\
\hline Days & 0 & 8 & 27 & 103 & 552 & 904 & 1355 & 1692 \\
\hline $\mathrm{CO}_{2}$ & 0.0 & 0.0 & 0.0 & 0.1 & 0.0 & 0.0 & 0.0 & 0.0 \\
\hline $\mathrm{N}_{2} \mathrm{O}$ & 0.0 & 0.0 & 0.0 & 0.0 & 0.0 & 0.0 & 0.0 & 0.0 \\
\hline $\mathrm{He}$ & 1.6 & 1.5 & 1.5 & 1.4 & 1.5 & 1.5 & 1.5 & 0.7 \\
\hline $\mathrm{H}_{2}$ & 0.0 & 0.0 & 0.1 & 0.1 & 0.1 & 0.0 & 0.0 & 0.0 \\
\hline $\mathrm{O}_{2}$ & 0.0 & 0.0 & 0.0 & 0.0 & 0.0 & 0.0 & 0.0 & 0.0 \\
\hline $\mathrm{N}_{2}$ & 0.1 & 0.1 & 0.1 & 0.1 & 0.2 & 0.2 & 0.2 & 0.2 \\
\hline $\mathrm{CH}_{4}$ & 0.0 & 0.0 & 0.0 & 0.0 & 0.0 & 0.0 & 0.0 & 0.0 \\
\hline $\mathrm{CO}$ & 0.0 & 0.0 & 0.0 & 0.0 & 0.0 & 0.0 & 0.0 & 0.0 \\
\hline
\end{tabular}


Appendix , Gas Generation: Total Pressure for SSR132

\begin{tabular}{|c|c|c|c|c|c|c|c|c|c|}
\hline Date & $\begin{array}{l}\text { Pressure } \\
(\mathrm{kPa})\end{array}$ & Date & $\begin{array}{l}\text { Pressure } \\
\text { (kPa) }\end{array}$ & Date & $\begin{array}{l}\text { Pressure } \\
\text { (kPa) }\end{array}$ & Date & $\begin{array}{l}\text { Pressure } \\
\text { (kPa) }\end{array}$ & Date & $\begin{array}{l}\text { Pressure } \\
\text { (kPa) }\end{array}$ \\
\hline $12 / 8 / 2003$ & & $4 / 12 / 2004$ & 88.0 & $8 / 16 / 2004$ & 91.4 & $12 / 20 / 2004$ & 92.0 & $4 / 25 / 2005$ & 90.1 \\
\hline $12 / 15 / 2003$ & & $4 / 19 / 2004$ & 88.8 & $8 / 23 / 2004$ & 91.6 & $12 / 27 / 2004$ & 92.1 & $5 / 2 / 2005$ & 89.9 \\
\hline $12 / 22 / 2003$ & & $4 / 26 / 2004$ & 88.8 & $8 / 30 / 2004$ & 91.7 & $1 / 3 / 2005$ & 92.1 & $5 / 9 / 2005$ & 89.8 \\
\hline $12 / 29 / 2003$ & & $5 / 3 / 2004$ & 89.4 & $9 / 6 / 2004$ & 92.0 & $1 / 10 / 2005$ & 91.9 & $5 / 16 / 2005$ & 89.4 \\
\hline $1 / 5 / 2004$ & & $5 / 10 / 2004$ & 89.7 & $9 / 13 / 2004$ & 92.3 & $1 / 17 / 2005$ & 91.9 & $5 / 23 / 2005$ & 89.0 \\
\hline $1 / 12 / 2004$ & 77.5 & $5 / 17 / 2004$ & 90.2 & 9/20/2004 & 92.5 & $1 / 24 / 2005$ & 91.9 & $5 / 30 / 2005$ & 88.4 \\
\hline $1 / 19 / 2004$ & 69.6 & $5 / 24 / 2004$ & 90.6 & $9 / 27 / 2004$ & 92.5 & $1 / 31 / 2005$ & 91.0 & 6/6/2005 & 88.1 \\
\hline $1 / 26 / 2004$ & 66.5 & $5 / 31 / 2004$ & 90.7 & $10 / 4 / 2004$ & 92.4 & $2 / 7 / 2005$ & 91.4 & $6 / 13 / 2005$ & 87.9 \\
\hline $2 / 2 / 2004$ & 67.0 & $6 / 7 / 2004$ & 90.8 & $10 / 11 / 2004$ & 92.6 & 2/14/2005 & 91.6 & $6 / 20 / 2005$ & 87.4 \\
\hline $2 / 9 / 2004$ & 63.2 & $6 / 14 / 2004$ & 90.1 & $10 / 18 / 2004$ & 92.6 & $2 / 21 / 2005$ & 91.5 & $6 / 27 / 2005$ & 87.6 \\
\hline $2 / 16 / 2004$ & 0.8 & $6 / 21 / 2004$ & 90.1 & $10 / 25 / 2004$ & 92.6 & $2 / 28 / 2005$ & 91.9 & $7 / 4 / 2005$ & 87.6 \\
\hline $2 / 23 / 2004$ & 9.5 & $6 / 28 / 2004$ & 90.5 & $11 / 1 / 2004$ & 92.4 & $3 / 7 / 2005$ & 92.1 & $7 / 11 / 2005$ & 87.5 \\
\hline $3 / 1 / 2004$ & 84.8 & $7 / 5 / 2004$ & 90.7 & $11 / 8 / 2004$ & 92.3 & $3 / 14 / 2005$ & 91.8 & $7 / 18 / 2005$ & 87.6 \\
\hline $3 / 8 / 2004$ & 85.1 & $7 / 12 / 2004$ & 90.8 & $11 / 15 / 2004$ & 92.3 & $3 / 21 / 2005$ & 91.5 & $7 / 25 / 2005$ & 87.7 \\
\hline $3 / 15 / 2004$ & 85.8 & $7 / 19 / 2004$ & 90.9 & $11 / 22 / 2004$ & 92.3 & $3 / 28 / 2005$ & 91.3 & $8 / 1 / 2005$ & 88.3 \\
\hline $3 / 22 / 2004$ & 86.3 & $7 / 26 / 2004$ & 90.8 & $11 / 29 / 2004$ & 92.2 & 4/4/2005 & 91.0 & $8 / 8 / 2005$ & 88.5 \\
\hline $3 / 29 / 2004$ & 86.7 & $8 / 2 / 2004$ & 91.0 & $12 / 6 / 2004$ & 92.2 & $4 / 11 / 2005$ & 90.8 & $8 / 15 / 2005$ & 88.5 \\
\hline $4 / 5 / 2004$ & 87.1 & $8 / 9 / 2004$ & 91.2 & $12 / 13 / 2004$ & 92.1 & 4/18/2005 & 90.5 & $8 / 22 / 2005$ & 88.4 \\
\hline
\end{tabular}


Appendix 2, Gas Generation: Total Pressure for SSR132 (continued)

\begin{tabular}{|c|c|c|c|c|c|c|c|}
\hline Date & $\begin{array}{l}\text { Pressure } \\
(\mathrm{kPa})\end{array}$ & Date & $\begin{array}{l}\text { Pressure } \\
(\mathrm{kPa})\end{array}$ & Date & $\begin{array}{l}\text { Pressure } \\
(\mathrm{kPa})\end{array}$ & Date & $\begin{array}{l}\text { Pressure } \\
(\mathrm{kPa})\end{array}$ \\
\hline $8 / 29 / 2005$ & 88.6 & $1 / 2 / 2006$ & 84.7 & $6 / 19 / 2006$ & 81.2 & $10 / 23 / 2006$ & 73.1 \\
\hline $9 / 5 / 2005$ & 87.9 & $1 / 9 / 2006$ & 84.4 & $6 / 26 / 2006$ & 80.7 & $10 / 30 / 2006$ & 73.2 \\
\hline 9/12/2005 & 87.9 & $1 / 16 / 2006$ & 84.2 & $7 / 3 / 2006$ & 80.1 & $11 / 6 / 2006$ & 73.5 \\
\hline $9 / 19 / 2005$ & 88.0 & $1 / 23 / 2006$ & 84.3 & $7 / 10 / 2006$ & 79.5 & $11 / 13 / 2006$ & 67.0 \\
\hline 9/26/2005 & 88.3 & $1 / 30 / 2006$ & 84.0 & $7 / 17 / 2006$ & & $11 / 20 / 2006$ & 73.6 \\
\hline $10 / 3 / 2005$ & 88.2 & $2 / 6 / 2006$ & 83.8 & $7 / 24 / 2006$ & 79.5 & $11 / 27 / 2006$ & 73.8 \\
\hline $10 / 10 / 2005$ & 88.2 & $2 / 13 / 2006$ & 84.4 & $7 / 31 / 2006$ & 78.3 & $12 / 4 / 2006$ & 73.8 \\
\hline $10 / 17 / 2005$ & 88.2 & $2 / 20 / 2006$ & 84.6 & $8 / 7 / 2006$ & 77.7 & $12 / 11 / 2006$ & 75.1 \\
\hline $10 / 24 / 2005$ & 88.2 & $4 / 10 / 2006$ & 85.4 & $8 / 14 / 2006$ & 77.3 & $12 / 18 / 2006$ & 75.3 \\
\hline $10 / 31 / 2005$ & 87.9 & $4 / 17 / 2006$ & 84.8 & $8 / 21 / 2006$ & 77.0 & $12 / 25 / 2006$ & 75. \\
\hline $11 / 7 / 2005$ & 87.9 & $4 / 24 / 2006$ & 84.0 & $8 / 28 / 2006$ & 76.5 & $1 / 1 / 2007$ & 75.5 \\
\hline $11 / 14 / 2005$ & 88.3 & $5 / 1 / 2006$ & 83.8 & $9 / 4 / 2006$ & 76.1 & $1 / 8 / 2007$ & 75.6 \\
\hline $11 / 21 / 2005$ & 87.2 & $5 / 8 / 2006$ & 83.4 & 9/11/2006 & 75.7 & $1 / 15 / 2007$ & 75.6 \\
\hline $11 / 28 / 2005$ & 86.8 & $5 / 15 / 2006$ & 83.1 & $9 / 18 / 2006$ & 75.3 & $1 / 22 / 2007$ & 75. \\
\hline $12 / 5 / 2005$ & 86.4 & $5 / 22 / 2006$ & 82.8 & $9 / 25 / 2006$ & 74.8 & & \\
\hline $12 / 12 / 2005$ & 86.2 & $5 / 29 / 2006$ & & $10 / 2 / 2006$ & 74.7 & & \\
\hline $12 / 19 / 2005$ & 84.1 & $6 / 5 / 2006$ & 82.2 & $10 / 9 / 2006$ & 74.3 & & \\
\hline $12 / 26 / 2005$ & 85.3 & $6 / 12 / 2006$ & 81.7 & $10 / 16 / 2006$ & 73.7 & & \\
\hline
\end{tabular}


Appendix 3, Gas Generation: Total Pressure for SSR132A

\begin{tabular}{|c|c|c|c|c|c|c|c|c|c|}
\hline Date & $\begin{array}{l}\text { Pressure } \\
(\mathrm{kPa})\end{array}$ & Date & $\begin{array}{l}\text { Pressure } \\
(\mathrm{kPa})\end{array}$ & Date & $\begin{array}{l}\text { Pressure } \\
(\mathrm{kPa})\end{array}$ & Date & $\begin{array}{l}\text { Pressure } \\
(\mathrm{kPa})\end{array}$ & Date & $\begin{array}{l}\text { Pressure } \\
(\mathrm{kPa})\end{array}$ \\
\hline $6 / 11 / 2008$ & 84.68 & $10 / 13 / 2008$ & 89.10 & $2 / 23 / 2009$ & 89.16 & 6/29/2009 & 88.53 & $11 / 2 / 2009$ & 90.07 \\
\hline 6/16/2008 & 84.23 & $10 / 20 / 2008$ & 89.24 & $3 / 2 / 2009$ & 89.09 & $7 / 6 / 2009$ & 88.51 & $11 / 9 / 2009$ & 90.36 \\
\hline $6 / 23 / 2008$ & 83.92 & $10 / 27 / 2008$ & 89.33 & $3 / 9 / 2009$ & 88.99 & $7 / 13 / 2009$ & 88.64 & $11 / 16 / 2009$ & 90.25 \\
\hline 6/30/2008 & 85.41 & $11 / 3 / 2008$ & 89.39 & $3 / 16 / 2009$ & 89.02 & $7 / 20 / 2009$ & 88.67 & $11 / 23 / 2009$ & 90.31 \\
\hline $7 / 7 / 2008$ & 86.15 & $11 / 10 / 2008$ & 89.21 & $3 / 23 / 2009$ & 89.02 & $7 / 27 / 2009$ & 88.84 & $11 / 30 / 2009$ & 90.25 \\
\hline $7 / 14 / 2008$ & 86.35 & $11 / 17 / 2008$ & 89.29 & $3 / 30 / 2009$ & 88.95 & $8 / 3 / 2009$ & 88.87 & $12 / 7 / 2009$ & 90.32 \\
\hline $7 / 21 / 2008$ & 87.37 & $11 / 24 / 2008$ & 89.65 & $4 / 6 / 2009$ & 88.75 & $8 / 10 / 2009$ & 88.84 & $12 / 14 / 2009$ & 90.46 \\
\hline $7 / 28 / 2008$ & 88.29 & $12 / 1 / 2008$ & 89.52 & $4 / 13 / 2009$ & 88.78 & $8 / 17 / 2009$ & 88.82 & $12 / 21 / 2009$ & 89.79 \\
\hline $8 / 4 / 2008$ & 88.79 & $12 / 8 / 2008$ & 89.45 & $4 / 20 / 2009$ & 88.71 & $8 / 24 / 2009$ & 88.87 & $12 / 28 / 2009$ & 89.74 \\
\hline $8 / 11 / 2008$ & 89.36 & $12 / 15 / 2008$ & 89.51 & $4 / 27 / 2009$ & 89.04 & $8 / 31 / 2009$ & 89.02 & $1 / 4 / 2010$ & 89.73 \\
\hline $8 / 18 / 2008$ & 89.82 & $12 / 22 / 2008$ & 89.54 & $5 / 4 / 2009$ & 89.16 & $9 / 7 / 2009$ & 88.75 & $1 / 11 / 2010$ & 89.97 \\
\hline $8 / 25 / 2008$ & 90.12 & $12 / 29 / 2008$ & 89.45 & $5 / 11 / 2009$ & 89.22 & 9/14/2009 & 88.76 & $1 / 18 / 2010$ & 90.00 \\
\hline 9/1/2008 & 90.29 & $1 / 5 / 2009$ & 89.66 & $5 / 18 / 2009$ & 89.29 & $9 / 21 / 2009$ & 89.84 & $1 / 25 / 2010$ & 89.96 \\
\hline 9/8/2008 & 90.55 & $1 / 12 / 2009$ & 89.55 & $5 / 25 / 2009$ & 90.04 & 9/28/2009 & 90.07 & 2/1/2010 & 90.17 \\
\hline 9/15/2008 & 90.65 & $1 / 19 / 2009$ & 89.73 & $6 / 1 / 2009$ & 90.35 & $10 / 5 / 2009$ & 90.00 & $2 / 8 / 2010$ & 90.54 \\
\hline $9 / 22 / 2008$ & 90.70 & $1 / 26 / 2009$ & 89.71 & $6 / 8 / 2009$ & 90.05 & $10 / 12 / 2009$ & 90.03 & $2 / 15 / 2010$ & 90.68 \\
\hline $9 / 29 / 2008$ & 89.05 & $2 / 2 / 2009$ & 89.66 & $6 / 15 / 2009$ & 89.30 & 10/19/2009 & 90.00 & $2 / 22 / 2010$ & 90.41 \\
\hline
\end{tabular}




\section{Appendix 3, Gas Generation: Total Pressure for SSR132A (continued)}

\begin{tabular}{|c|c|c|c|c|c|c|c|c|c|}
\hline Date & $\begin{array}{l}\text { Pressure } \\
(\mathrm{kPa})\end{array}$ & Date & $\begin{array}{l}\text { Pressure } \\
(\mathrm{kPa})\end{array}$ & Date & $\begin{array}{l}\text { Pressure } \\
(\mathrm{kPa})\end{array}$ & Date & $\begin{array}{l}\text { Pressure } \\
(\mathrm{kPa})\end{array}$ & Date & $\begin{array}{l}\text { Pressure } \\
(\mathrm{kPa})\end{array}$ \\
\hline $3 / 8 / 2010$ & 90.55 & $7 / 12 / 2010$ & 91.39 & $11 / 15 / 2010$ & 92.62 & $3 / 21 / 2011$ & 92.34 & $7 / 25 / 2011$ & 85.84 \\
\hline $3 / 15 / 2010$ & 90.72 & $7 / 19 / 2010$ & 91.21 & $11 / 22 / 2010$ & 92.80 & $3 / 28 / 2011$ & 92.47 & $8 / 1 / 2011$ & 93.00 \\
\hline $3 / 22 / 2010$ & 90.73 & $7 / 26 / 2010$ & 91.12 & $11 / 29 / 2010$ & 92.74 & $4 / 4 / 2011$ & 92.27 & 8/8/2011 & 93.03 \\
\hline $3 / 29 / 2010$ & 90.83 & $8 / 2 / 2010$ & 91.07 & $12 / 6 / 2010$ & 91.60 & $4 / 11 / 2011$ & 92.25 & $8 / 15 / 2011$ & 92.95 \\
\hline $4 / 5 / 2010$ & 90.64 & $8 / 9 / 2010$ & 90.93 & $12 / 13 / 2010$ & 91.75 & $4 / 18 / 2011$ & 92.27 & $8 / 22 / 2011$ & 92.84 \\
\hline $4 / 12 / 2010$ & 90.71 & $8 / 16 / 2010$ & 91.03 & $12 / 20 / 2010$ & 91.61 & $4 / 25 / 2011$ & 92.31 & $8 / 29 / 2011$ & 92.85 \\
\hline $4 / 19 / 2010$ & 90.69 & $8 / 23 / 2010$ & 91.18 & $12 / 27 / 2010$ & 91.73 & $5 / 2 / 2011$ & 92.47 & $9 / 5 / 2011$ & 93.06 \\
\hline $4 / 26 / 2010$ & 90.69 & $8 / 30 / 2010$ & 91.13 & $1 / 3 / 2011$ & 91.43 & $5 / 9 / 2011$ & 92.49 & 9/12/2011 & 93.03 \\
\hline $5 / 3 / 2010$ & 90.71 & $9 / 6 / 2010$ & 91.46 & $1 / 10 / 2011$ & 91.59 & $5 / 16 / 2011$ & 92.43 & 9/19/2011 & 93.38 \\
\hline $5 / 10 / 2010$ & 91.03 & $9 / 13 / 2010$ & 91.19 & $1 / 17 / 2011$ & 91.60 & $5 / 23 / 2011$ & 92.32 & $9 / 26 / 2011$ & 93.56 \\
\hline $5 / 17 / 2010$ & 90.98 & 9/20/2010 & 91.73 & $1 / 24 / 2011$ & 91.67 & $5 / 30 / 2011$ & 92.21 & $10 / 3 / 2011$ & 93.52 \\
\hline $5 / 24 / 2010$ & 91.10 & $9 / 27 / 2010$ & 92.77 & $1 / 31 / 2011$ & 91.70 & $6 / 6 / 2011$ & 92.21 & $10 / 10 / 2011$ & 93.56 \\
\hline $5 / 31 / 2010$ & 91.19 & $10 / 4 / 2010$ & 91.46 & $2 / 7 / 2011$ & 91.66 & $6 / 13 / 2011$ & 92.53 & $10 / 17 / 2011$ & 93.79 \\
\hline $6 / 7 / 2010$ & 91.24 & $10 / 11 / 2010$ & 90.86 & $2 / 14 / 2011$ & 91.84 & $6 / 20 / 2011$ & 92.40 & $10 / 24 / 2011$ & 93.46 \\
\hline $6 / 14 / 2010$ & 91.46 & $10 / 18 / 2010$ & 90.76 & $2 / 21 / 2011$ & 91.98 & $6 / 27 / 2011$ & 92.60 & $10 / 31 / 2011$ & 93.41 \\
\hline $6 / 21 / 2010$ & 91.46 & $10 / 25 / 2010$ & 91.40 & $2 / 28 / 2011$ & 91.98 & $7 / 4 / 2011$ & 92.71 & $11 / 7 / 2011$ & 93.43 \\
\hline $6 / 28 / 2010$ & 91.52 & $11 / 1 / 2010$ & 92.53 & $3 / 7 / 2011$ & 92.15 & $7 / 11 / 2011$ & 92.92 & $11 / 14 / 2011$ & 93.45 \\
\hline
\end{tabular}


Appendix 3, Gas Generation: Total Pressure for SSR132A (continued)

\begin{tabular}{|c|c|c|c|c|c|c|c|}
\hline Date & $\begin{array}{l}\text { Pressure } \\
(\mathrm{kPa})\end{array}$ & Date & $\begin{array}{l}\text { Pressure } \\
(\mathrm{kPa})\end{array}$ & Date & $\begin{array}{l}\text { Pressure } \\
(\mathrm{kPa})\end{array}$ & Date & $\begin{array}{l}\text { Pressure } \\
(\mathrm{kPa})\end{array}$ \\
\hline $11 / 28 / 2011$ & 93.13 & $4 / 2 / 2012$ & 92.53 & 8/6/2012 & 93.40 & $12 / 10 / 2012$ & 92.87 \\
\hline $12 / 5 / 2011$ & 93.29 & $4 / 9 / 2012$ & 92.58 & $8 / 13 / 2012$ & 93.42 & $12 / 17 / 2012$ & 92.56 \\
\hline $12 / 12 / 2011$ & 93.36 & $4 / 16 / 2012$ & 92.68 & $8 / 20 / 2012$ & 93.33 & $12 / 24 / 2012$ & 92.88 \\
\hline $12 / 19 / 2011$ & 93.24 & $4 / 23 / 2012$ & 92.77 & $8 / 27 / 2012$ & 93.27 & $12 / 31 / 2012$ & 93.06 \\
\hline $12 / 26 / 2011$ & 93.31 & $4 / 30 / 2012$ & 92.35 & $9 / 3 / 2012$ & 93.23 & $1 / 7 / 2013$ & 93.01 \\
\hline $1 / 2 / 2012$ & 92.87 & $5 / 7 / 2012$ & 92.60 & 9/10/2012 & 93.58 & $1 / 14 / 2013$ & 92.96 \\
\hline $1 / 9 / 2012$ & 93.31 & $5 / 14 / 2012$ & 93.55 & 9/17/2012 & 93.45 & $1 / 21 / 2013$ & 93.00 \\
\hline $1 / 16 / 2012$ & 93.49 & $5 / 21 / 2012$ & 93.76 & 9/24/2012 & 93.40 & $1 / 28 / 2013$ & 93.35 \\
\hline $1 / 23 / 2012$ & 94.15 & $5 / 28 / 2012$ & 93.77 & $10 / 1 / 2012$ & 93.48 & & \\
\hline 1/30/2012 & 93.94 & 6/4/2012 & 93.71 & $10 / 8 / 2012$ & 93.30 & & \\
\hline 2/6/2012 & 93.65 & $6 / 11 / 2012$ & 94.07 & $10 / 15 / 2012$ & 93.37 & & \\
\hline 2/13/2012 & 93.61 & $6 / 18 / 2012$ & 93.84 & $10 / 22 / 2012$ & 93.44 & & \\
\hline 2/20/2012 & 93.68 & $6 / 25 / 2012$ & 93.76 & $10 / 29 / 2012$ & 93.49 & & \\
\hline $2 / 27 / 2012$ & 92.62 & $7 / 2 / 2012$ & 93.68 & $11 / 5 / 2012$ & 93.38 & & \\
\hline $3 / 5 / 2012$ & 92.65 & $7 / 9 / 2012$ & 93.50 & $11 / 12 / 2012$ & 93.27 & & \\
\hline $3 / 12 / 2012$ & 92.80 & $7 / 16 / 2012$ & 93.55 & 11/19/2012 & 93.23 & & \\
\hline 3/19/2012 & 92.70 & $7 / 23 / 2012$ & 93.36 & $11 / 26 / 2012$ & 93.32 & & \\
\hline
\end{tabular}




\section{Appendix 4, Estimating the monolayer coverage}

Surface Area: The number of monolayers of moisture on the sample surface may be calculated if the mass of moisture/water, the mass of the sample, and the SSA of the sample are known. One approach is to determine the weight percentage for one monolayer of water. The number of monolayers of water can be calculated by dividing the total weight percentage of water (mass of water/mass of the sample) by the weight percentage of one monolayer of water. ${ }^{13}$ The weight percentage of one monolayer of water is the product of the weight of water in a monolayer of $1 \mathrm{~m}^{2}$ and the SSA:

$$
\begin{gathered}
\text { wt } \% \text { of } 1 \mathrm{ML}=0.00022 \mathrm{~g} \mathrm{~m}^{-2} \mathrm{ML}^{-1} \times \mathrm{SSA} \mathrm{m}^{2} \mathrm{~g}^{-1} \times 100 \mathrm{wt} \% \\
=0.022 \mathrm{wt} \% \mathrm{ML}^{-1} \times \mathrm{SSA} .
\end{gathered}
$$

For the material BLO-39-11-14-004, with a SSA of $2.4 \mathrm{~m}^{2} \mathrm{~g}^{-1}$, the weight percentage of one monolayer of water is $0.053 \mathrm{wt} \%$.

Dividing the weight percentage of water by the weight percentage of water in one monolayer yields the number of monolayers of water. Applying this to the measured weight percentage of water upon loading and unloading results in:

\begin{tabular}{|c|c|c|}
\hline & \multicolumn{2}{|c|}{ Total Moisture Loading (TGA) } \\
\hline & SSR 132 & SSR132A \\
\hline Wt\% Moisture & 0.60 & 0.59 \\
\hline ML & 11.3 & 11.1 \\
\hline
\end{tabular}




\section{Appendix 4, Estimating the monolayer coverage (continued)}

BET Theory: The number of monolayers can also be estimated based upon the relative humidity in the container using Brunauer-Emmett-Teller (BET) theory. ${ }^{9}$ BET theory is the standard model for quantifying the equilibria between multiple physically adsorbed layers on a surface and the adsorbing species in the gas above the surface. The specific relationship between the $\mathrm{RH}$ above a surface and the number of monolyers of weakly bound water on the surface predicted by BET theory is illustruated in Fig. A-1. We will use $c=7$ for high-purity plutonium dioxide because it is within the range observed. ${ }^{14}$

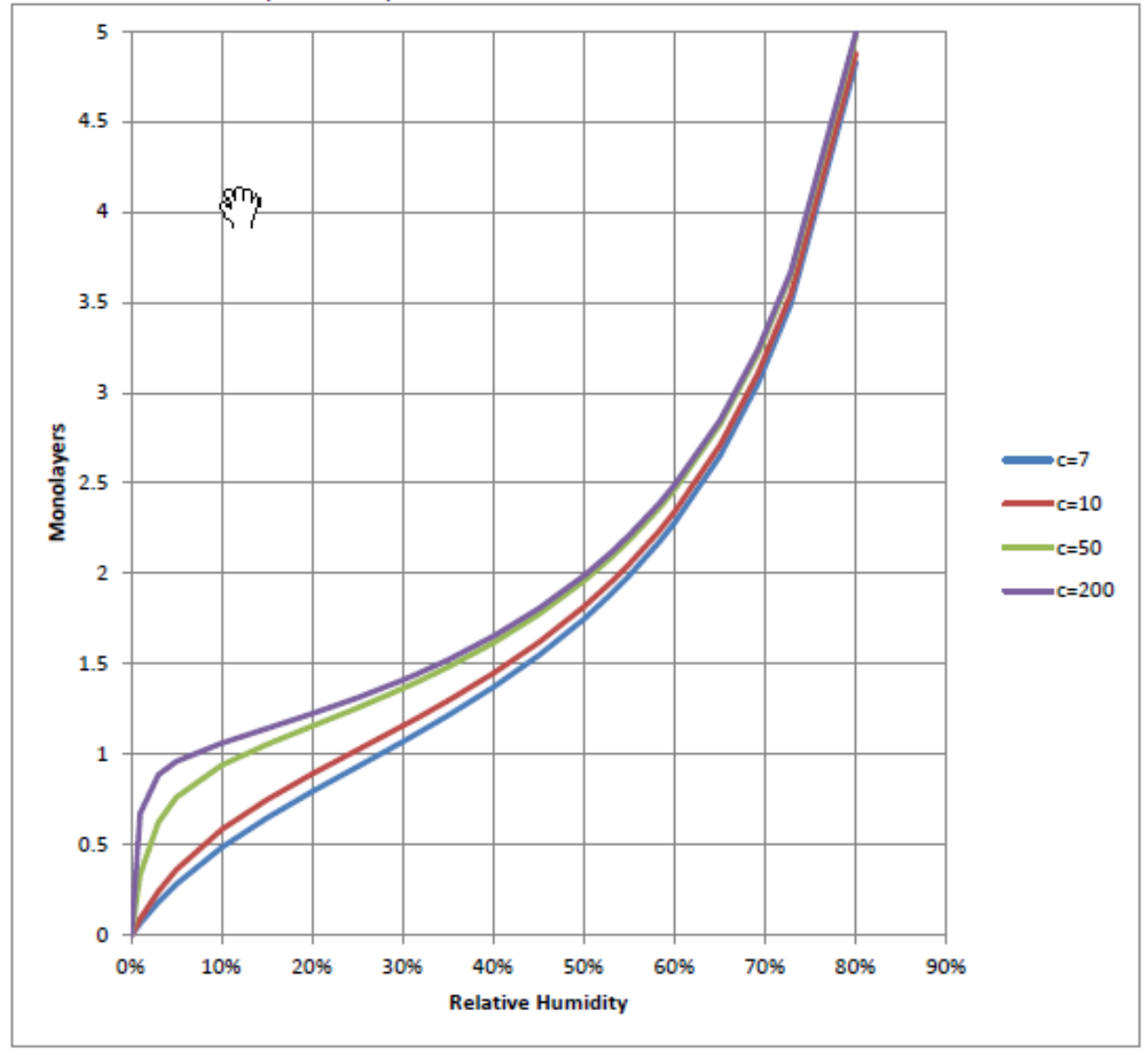

Figure A-1. Adsorption Isotherm Calculated from BET Theory. 


\section{Appendix 5, Stopping power ratio}

The ratio of the stopping power due to the water and the stopping power due to the material is calculated using the approach in Appendix B of Reference 6. Elements with greater than $0.3 \mathrm{wt} \%$ were included.

\begin{tabular}{|c|c|c|c|}
\hline $\begin{array}{l}\text { Element or } \\
\text { Compound }\end{array}$ & $\begin{array}{c}\text { Integrated Stopping } \\
\text { Power from } 0 \text { to } 5.2 \\
\mathrm{MeV}\left(\mathrm{mg}^{-1} \mathrm{~cm}^{-2}\right)\end{array}$ & $\begin{array}{l}\text { Elemental } \\
\text { Mass } \\
\text { Fraction } \\
\end{array}$ & $\begin{array}{c}\text { Elemental } \\
\text { Stopping Power } \\
\left(\mathrm{mg}^{-1} \mathrm{~cm}^{-2}\right)\end{array}$ \\
\hline $\mathrm{H} 2 \mathrm{O}(\mathrm{g})$ & 7.946 & 0.0000 & 0 \\
\hline H2O (l) & 7.708 & 0.0067 & 0.05164 \\
\hline $\mathrm{F}$ & 6.645 & 0.0000 & 0 \\
\hline $\mathrm{O}$ & 5.901 & 0.0084 & 0.049521 \\
\hline $\mathrm{Na}$ & 5.304 & 0.0000 & 0 \\
\hline $\mathrm{C}$ & 5.190 & 0.0021 & 0.0109 \\
\hline $\mathrm{S}$ & 5.117 & 0.0000 & 0 \\
\hline $\mathrm{Mg}$ & 5.100 & 0.0006 & 0.003264 \\
\hline $\mathrm{Si}$ & 4.852 & 0.0000 & 0 \\
\hline $\mathrm{Al}$ & 4.702 & 0.0000 & 0 \\
\hline $\mathrm{K}$ & 4.652 & 0.0003 & 0.001442 \\
\hline $\mathrm{Cl}$ & 4.575 & 0.0010 & 0.004575 \\
\hline $\mathrm{Ca}$ & 4.461 & 0.0000 & 0 \\
\hline $\mathrm{Cr}$ & 3.688 & 0.0000 & 0 \\
\hline $\mathrm{Fe}$ & 3.504 & 0.0000 & 0 \\
\hline $\mathrm{Ni}$ & 3.184 & 0.0000 & 0 \\
\hline $\mathrm{Cu}$ & 2.871 & 0.0000 & 0 \\
\hline $\mathrm{Zn}$ & 2.860 & 0.0000 & 0 \\
\hline $\mathrm{Ga}$ & 2.786 & 0.0000 & 0 \\
\hline$(\mathrm{Pu}+\mathrm{U}+\mathrm{Am}) \mathrm{O} 2$ & 2.081 & .988 & 2.055050 \\
\hline & & Smat & 2.124755 \\
\hline & & Swat & 7.708 \\
\hline & & $\mathrm{S}$ & 3.63 \\
\hline
\end{tabular}




\section{Appendix 6, Obtaining G-values and rate constants}

As discussed in the $\mathrm{H}_{2} \mathrm{G}$-value and rate constants section, a double exponential growth function fits the time dependence of the partial pressure curve for hydrogen in many of the MIS studies. The double exponential has three fitting parameters, $A_{0}$, the initial active water, $\mathrm{k}_{1}$ the hydrogen formation rate constant and $\mathrm{k}_{2}$, the hydrogen consumption rate constant. These fitting parameters can be used along with information of material properties and container geometry to calculate the initial rate, the hydrogen G-value, and empirical rate constants. This appendix documents the methodology for obtaining this information.

\section{Calculation of $G\left(H_{2}\right)$}

$G\left(H_{2}\right)$ can be calculated by equating the initial rate of hydrogen generation to the product of the rate of dose to the water and $G\left(\mathrm{H}_{2}\right)$,

$$
\frac{d n_{\mathrm{H}_{2}}}{d t}=\dot{D}_{\mathrm{H}_{2} \mathrm{O}} G\left(\mathrm{H}_{2}\right)
$$

Equation A6-1

where $N_{\mathrm{H} 2}$ is the number of molecules of hydrogen and $\dot{D}_{\mathrm{H} 2 \mathrm{O}}$ is the rate of adsorbed dose to the water with units $\mathrm{eV} \mathrm{s}^{-1}$. The initial rate is given by the differential

$$
\frac{d P_{H 2}}{d t}=k_{1} A_{0} e^{-k_{1} t}-k_{2} P_{H 2}
$$

evaluated at time zero in units of molecules per second rather than $\mathrm{kPa}$ per day, given $P_{H 2}$ is zero at $\mathrm{t}=0$.

$$
\begin{gathered}
\left.\left.\frac{d P}{d t}\right]_{t=0}=k_{1} A_{0} e^{-b t}\right]_{t=0}=k_{1} A_{0} \\
\frac{d n_{H_{2}}}{d t}=\frac{d P}{d t} \frac{V_{g} N_{A}}{R T}=k_{1} A_{0} \frac{V_{g} N_{A}}{R T} \frac{d a y}{86400 \mathrm{~s}} \\
k_{1} A_{0} \frac{V_{g} N_{A}}{R T} \frac{d a y}{86400 \mathrm{~s}}=\dot{D}_{\mathrm{H}_{2} O} G\left(H_{2}\right)
\end{gathered}
$$

Equation A6-2

In Equation A6-2, $V_{g}$ is the gas volume within the reactor, $N_{A}$ is Avogadro's number, $R$ is the universal gas constant, $T$ is the temperature in the gas phase during the time the data was collected. The method for calculating $V_{g}$ within an SSR is shown in the Loading section. The dose rate to the water is given by 


\section{Appendix 6, Obtaining G-values and rate constants (continued)}

$$
\begin{gathered}
\dot{D}_{\mathrm{H}_{2} \mathrm{O}}=P_{\text {mat }} \frac{6.2418 \times 10^{18} \mathrm{eV}}{\mathrm{s} \mathrm{W}} m_{m a t} f_{\mathrm{H}_{2} \mathrm{O}} \frac{S_{\mathrm{H}_{2} \mathrm{O}}}{S_{m a t}} \\
f_{\mathrm{H}_{2} \mathrm{O}}=\frac{m_{\mathrm{H}_{2} \mathrm{O}}}{m_{m a t}} \\
\dot{D}_{\mathrm{H}_{2} \mathrm{O}}=P_{\text {mat }} \frac{6.2418 \times 10^{18} \mathrm{eV}}{\mathrm{s} \mathrm{W}} m_{\mathrm{H}_{2} \mathrm{O}} \frac{S_{\mathrm{H}_{2} \mathrm{O}}}{S_{\text {mat }}}
\end{gathered}
$$

Equation A6-3

where $P_{\text {mat }}$ is the specific power of the material in $\mathrm{W} \mathrm{g}^{-1}, m_{\text {mat }}$ is the mass of the material, $f_{\mathrm{H} 2 \mathrm{O}}$ is the fraction of water, and the ratio $S_{\mathrm{H} 2 \mathrm{O}} / S_{\text {mat }}$ is the ratio of the stopping power of alpha particles in water to the stopping power in the material. An approach for calculating $S_{\mathrm{H} 2 \mathrm{O}} / S_{\text {mat }}$ is given in Appendix B. For high-purity plutonium dioxide with adsorbed water and no impurities the ratio $S_{\mathrm{H} 2 \mathrm{O}} / S_{\text {mat }}$ for $5.2 \mathrm{MeV} \alpha$-particles is $~ 3.70$. Combining Equation A6-2 and Equation A6-3 yields a general expression for $G\left(\mathrm{H}_{2}\right)$ using the fitting parameters $\mathrm{k}_{1}$ and $\mathrm{A}_{0}$, and the material properties,

$$
G\left(H_{2}\right)=k_{1} A_{0} \frac{V_{g} N_{A}}{R T} \frac{\text { day }}{86400 \mathrm{~s}} \frac{1}{P_{\text {mat }} \frac{6.2418 \times 10^{18} \mathrm{eV} / 100}{\mathrm{sW}} m_{\mathrm{H}_{2} O} \mathrm{O}} \frac{1}{\frac{S_{H_{2} O} O}{S_{\text {mat }}}}
$$

Equation A6-4

\section{Conversion of rate constants}

The surface formation rate constant, $\boldsymbol{k}_{\boldsymbol{f} \text { or }}$, is determined from the initial rate and can be expressed in terms of molecules of hydrogen produced per second using Eq. A6-5.

$$
k_{\text {for }}=k_{1} A_{0} \frac{V_{g} N_{A}}{R T} \frac{d a y}{86400 s}
$$

Equation A6-5

The consumption rate constant, $k_{2}$, expressed in units of days ${ }^{-1}$, can be expressed in terms of molecules of hydrogen consumed per second per kPa of hydrogen using Eq. A6-6.

$$
k_{\text {con }}=k_{2} \frac{V_{g} N_{A}}{R T} \frac{d a y}{86400 s}
$$

Equation A6-6 


\section{Appendix 6, Obtaining G-values and rate constants (continued)}

\section{Calculation of rate constants for surface catalyzed decomposition of water to form $\mathrm{H}_{2}$}

The surface catalyzed decomposition of water to form $\mathrm{H}_{2}$ has been proposed by Haschke and coworkers. ${ }^{15}$ The reaction is described by,

$$
\mathrm{PuO}_{2}(\mathrm{~s})+x \mathrm{H}_{2} \mathrm{O}(\text { ads. }) \rightarrow \mathrm{PuO}_{2+x}(\mathrm{~s})+x \mathrm{H}_{2}(\mathrm{~g})
$$

Equation A6-7

The reaction "contributes to $\mathrm{H}_{2}$ pressurization of sealed storage containers until the equilibrium pressure of Equation A6-7 is reached." "15a The amount of solid plutonium dioxide and water is large compared to the amount of $\mathrm{H}_{2}$ and higher oxide produced. The initial reaction rate will be essentially constant throughout the reaction. The $\mathrm{H}_{2}$ consumption reaction, in this case a true back reaction, is first order in $\mathrm{H}_{2}$ partial pressure and in the amount of the higher oxide. The rate was found to be independent of adsorbed water over a wide range of adsorbed water. The observed initial rate of formation is divided by the total surface area of the material to obtain values that can be compared to Haschke's reaction rates,

$$
\mathrm{R}_{\text {for }}=A_{0} k_{1} \frac{d a y}{24 h r} \frac{V_{g}}{R T} \frac{1}{S S A m_{\text {mat }}}
$$

Equation A6-8,

where SSA is the specific surface area of the material and $m_{\text {mat }}$.is the mass of the plutonium dioxide. This formation rate, $\mathrm{R}_{\mathrm{for}}$, is expressed in units of moles $\mathrm{m}^{-2} \mathrm{hr}^{-1} \mathrm{kPa}^{-1}$ of active water. The rate of the surface catalyzed consumption reaction is given by

$$
\mathrm{R}_{\mathrm{con}}=k_{2} \frac{d a y}{24 h r} \frac{V_{g}}{R T} \frac{1}{S S A m_{m a t}}
$$

Equation A6-9. 


\section{Appendix 7, Symbols and Conversion Factors}

Symbols

\begin{tabular}{|c|c|c|}
\hline Symbol & Units & Description \\
\hline A & $\mathrm{kPa}$ & Active water or the water involved in hydrogen generation \\
\hline$A_{0}$ & $\mathrm{kPa}$ & $\begin{array}{l}\text { Initial active water (fitting parameter based on the reaction } \\
\text { model) }\end{array}$ \\
\hline$k_{1}$ & day $^{-1}$ & $\begin{array}{l}\text { Rate constant for the formation of hydrogen from water } \\
\text { (fitting parameter based on the reaction model) }\end{array}$ \\
\hline$k_{2}$ & day $^{-1}$ & $\begin{array}{l}\text { Rate constant for the consumption of hydrogen (fitting } \\
\text { parameter based on the reaction model) }\end{array}$ \\
\hline$\dot{\mathrm{D}}_{\mathrm{x}}$ & $\mathrm{eV} \mathrm{s}^{-1}$ or $\mathrm{J} \mathrm{s}^{-1}$ or $\mathrm{W}$ & Rate of adsorbed dose to $\mathrm{x}$ \\
\hline$G(x)$ & molecules $100 \mathrm{eV}^{-1}$ & $\begin{array}{l}\text { Number of molecules of } \mathrm{x} \text { produced per } 100 \mathrm{eV} \text { of adsorbed } \\
\text { dose }\end{array}$ \\
\hline$f_{x}$ & --- & Fraction of material $\mathrm{x}$ in the total material \\
\hline$m_{x}$ & g & Mass of $x$ \\
\hline$N_{x}$ & molecules & Number of molecules of substance $\mathrm{x}$ \\
\hline $\mathrm{N}_{\mathrm{A}}$ & molecules $\mathrm{mol}^{-1}$ & Avogadros number \\
\hline$p_{x}$ & $\mathrm{kPa}$ & Partial pressure of $x$ \\
\hline$P_{x}$ & $\mathrm{~W} \mathrm{~g}^{-1}$ or $\mathrm{eV} \mathrm{s}^{-1} \mathrm{~g}^{-1}$ & Specific power of $x$ \\
\hline$S_{x}$ & $\mathrm{~m}$ & Stopping power of $\mathrm{x}$ to alpha radiation \\
\hline SSA & $m^{2} g^{-1}$ & Specific Surface Area of the material \\
\hline$t$ & s or day or yr & Time \\
\hline $\mathrm{T}$ & $\mathrm{K}$ & Temperature \\
\hline$V_{g}$ & $\mathrm{~cm}^{3}$ & Volume that the gas occupies \\
\hline
\end{tabular}




\section{Appendix 7, Symbols and Conversion Factors (continued)}

\section{Unit conversions}

\begin{tabular}{|c|l|}
\hline $1 \mathrm{~W}$ & $6.2418 \times 10^{18} \mathrm{eV} \mathrm{s}^{-1}$ \\
\hline 1 day & $86400 \mathrm{~s}$ \\
\hline 1 day & $24 \mathrm{hr}$ \\
\hline $\mathrm{N}_{\mathrm{A}}$ & $6.0221367 \times 10^{23} \mathrm{molecules} \mathrm{mol}^{-1}$ \\
\hline $\mathrm{R}$ & $8.314510 \mathrm{~J} \mathrm{~mol}^{-1} \mathrm{~K}^{-1}$ \\
& $8.314510 \mathrm{kPa} \mathrm{L} \mathrm{mol}^{-1} \mathrm{~K}^{-1}$ \\
& $8314.510 \mathrm{kPa} \mathrm{cm}^{3} \mathrm{~mol}^{-1} \mathrm{~K}^{-1}$ \\
\hline
\end{tabular}

